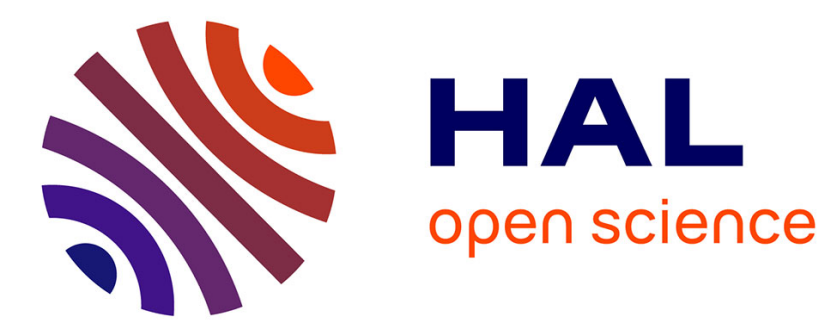

\title{
Deformation partitioning in flat subduction setting: Case of the Andean foreland of western Argentina $\left(28^{\circ} \mathrm{S}-33^{\circ} \mathrm{S}\right)$
}

\author{
Lionel Siame, O Bellier, Michel Sébrier, M. Araujo
}

\section{- To cite this version:}

Lionel Siame, O Bellier, Michel Sébrier, M. Araujo. Deformation partitioning in flat subduction setting: Case of the Andean foreland of western Argentina (28 $\left.{ }^{\circ} \mathrm{S}-33^{\circ} \mathrm{S}\right)$. Tectonics, 2005, 24, pp.1-24. 10.1029/2005TC001787 . hal-00022417

\section{HAL Id: hal-00022417 https://hal.science/hal-00022417}

Submitted on 19 Feb 2021

HAL is a multi-disciplinary open access archive for the deposit and dissemination of scientific research documents, whether they are published or not. The documents may come from teaching and research institutions in France or abroad, or from public or private research centers.
L'archive ouverte pluridisciplinaire HAL, est destinée au dépôt et à la diffusion de documents scientifiques de niveau recherche, publiés ou non, émanant des établissements d'enseignement et de recherche français ou étrangers, des laboratoires publics ou privés. 


\title{
Deformation partitioning in flat subduction setting: Case of the Andean foreland of western Argentina $\left(28^{\circ} \mathrm{S}-33^{\circ} \mathrm{S}\right)$
}

\author{
L. L. Siame and O. Bellier \\ Cézanne, Aix-en-Provence, France

\section{Sébrier} \\ Laboratoire de Tectonique, UMR 7072, Université Pierre et Marie Curie, Paris, France \\ M. Araujo \\ Instituto Nacional de Prevención Sísmica, San Juan, Argentina
}

Centre Européen de Recherche et d'Enseignement de Géosciences de l'Environnement, UMR 6635, Université Paul

Received 10 January 2005; revised 12 May 2005; accepted 17 June 2005; published 13 September 2005.

[1] The Andean foreland of western Argentina $\left(28^{\circ} \mathrm{S}-33^{\circ} \mathrm{S}\right)$ corresponds to back arc deformations associated with the ongoing flat subduction of the Nazca plate beneath the South American lithosphere. In this paper, short- and long-term tectonic regimes for this Andean region are investigated and compared to NUVEL-1 and the new GPS-derived velocity field for the Andes Mountains. From this comparison, it appears that (1) the slight convergence obliquity at the plate boundary is accommodated by the subduction zone itself, precluding any deformation partitioning at lithospheric scale, (2) clockwise rotation of $\sigma_{1}$ and $P$ axes within the Andean foreland of western Argentina suggests that PlioQuaternary deformation partitioning may occur in the upper plate at crustal scale, and (3) comparison of seismic rates of shallow deformations determined from moderate to large earthquakes localized between $22^{\circ} \mathrm{S}$ and $36^{\circ} \mathrm{S}$ shows that the amount of shortening is about the same $\left(2-4 \mathrm{~cm} \mathrm{yr}^{-1}\right)$ between the forearcs of the $30^{\circ}$ dipping slab segments and the back arc of the flat segment. All together, those observations are in close agreement with the idea that interplate coupling in flat subduction settings may play a key role in the presentday transfer of plate boundary forces. Consequently, the Andean back arc of western Argentina might be regarded as an obliquely converging foreland where Plio-Quaternary deformations are partitioned between strike-slip and thrust motions that are localized in the east verging thin-skinned Argentine Precordillera and west verging thick-skinned Pampean Ranges, respectively. Citation: Siame, L. L., O. Bellier, M. Sébrier, and M. Araujo (2005), Deformation partitioning in flat subduction setting: Case of the Andean foreland of western Argentina $\left(28^{\circ} \mathrm{S}-\right.$ $33^{\circ}$ S), Tectonics, 24, TC5003, doi:10.1029/2005TC001787.

Copyright 2005 by the American Geophysical Union. 0278-7407/05/2005TC001787

\section{Introduction}

[2] Along the Andes, variations in tectonic style coincide with changes in the geometry of the subducted Nazca plate [e.g., Ramos, 1999, and references herein]. Among those variations, high levels of crustal seismicity characterize the back arc of the South American plate above flat slab segments (Figure 1), seismic moment releases being generally 3 or 5 times greater than above $30^{\circ}$ dipping segments [Gutscher et al., 2000]. The Andean foreland of western Argentina $\left(28^{\circ} \mathrm{S}-33^{\circ} \mathrm{S}\right)$ corresponds to such back arc deformation associated with the ongoing subduction of the Pampean flat slab segment which proceeds nearly horizontally beneath the South American lithosphere for roughly $300 \mathrm{~km}$ at a depth of about $100 \mathrm{~km}$ [Cahill and Isacks, 1992; Smalley et al., 1993]. Coinciding with this change of the subducted Nazca plate dip [Jordan et al., 1983; Cahill and Isacks, 1992], the Andean foreland domain is characterized by two opposite verging, compressional structural provinces coexisting side by side: the east verging thin-skinned Argentine Precordillera fold-and-thrust belt and the west verging thick-skinned Pampean uplifted basement blocks. In this Andean region, the flat slab geometry is attributed to the subduction of the Juan Fernandez Ridge below the South American margin [Pilger, 1981], and expressed at the magmatic arc by a change in the geochemistry properties of the Neogene volcanism and a cessation of activity at roughly $10 \mathrm{Ma}$ [Kay and Abbruzzi, 1996]. As suggested by Gutscher et al. [2000], flat subduction could alter the thermal structure of the margin, cooling both upper and subducting plates, and thus greatly increases the strength of the upper lithosphere. Enhanced plate coupling above a flat subduction combined with a stronger rheology of the cooled upper lithosphere favor to transfer the deformation far into the upper plate, several hundred kilometers away from the trench. This process has long been suggested to be responsible for the large-scale, thick-skinned Pampean Ranges basement uplifts [Jordan et al., 1983; Smalley et al., 1993]. On the other hand, thermal weakness of the crust associated with eastward migration of arc magmatism as also been suggested to be responsible for thick-skinned basement uplift of the Sierras Pampeanas [Ramos et al., 2002]. 

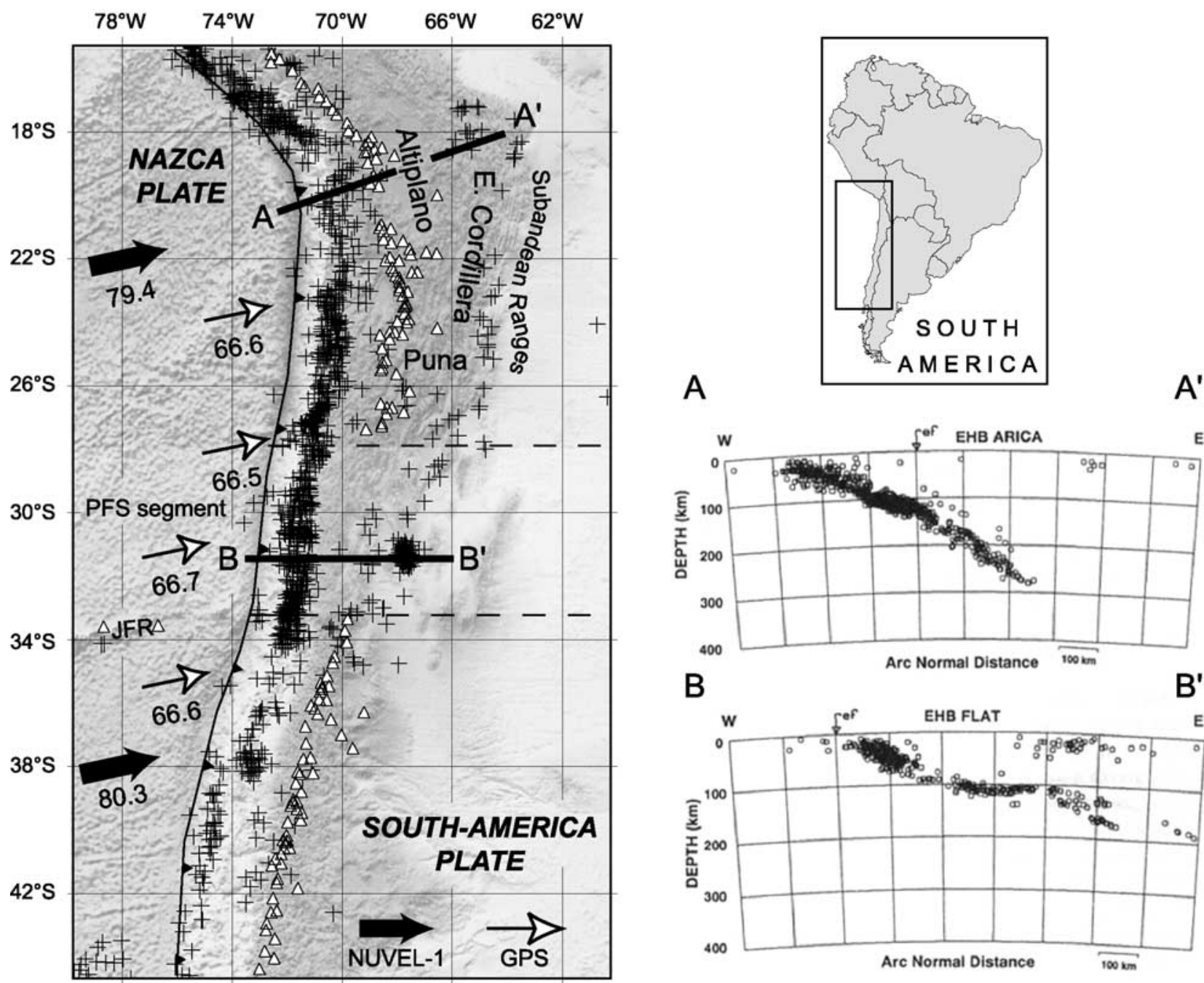

B

$B^{\prime}$

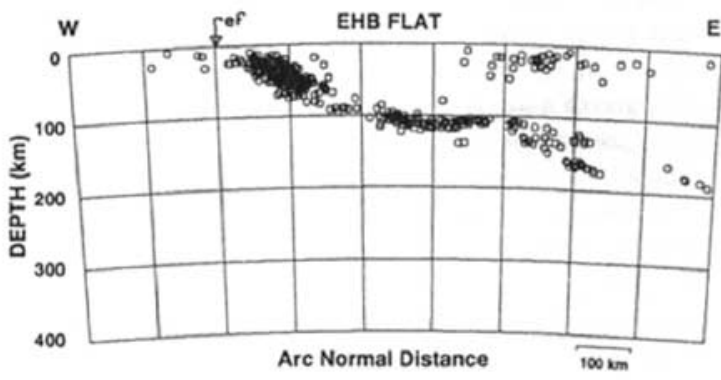

Figure 1. Map of the central Andes between $19^{\circ} \mathrm{S}$ and $43^{\circ} \mathrm{S}$ latitude (globe shaded relief after Hastings and Dunbar [1998] and bathymetry after Smith and Sandwell [1997]). Crosses represent the epicenter distribution of large to moderate earthquakes (U.S. Geological Survey, National Earthquake Information Center; Preliminary Determination Epicenter catalog, 1973 to present, depth $\leq 70 \mathrm{~km}, M \geq 5.0$ ); triangles correspond to Plio-Quaternary and active volcanoes. Black and white arrows represent the relative convergence of the Nazca and South American plates following NUVEL-1 [DeMets et al., 1990, 1994] and continuous GPS observation [Kendrick et al., 1999, 2003], respectively. Numbers are given in $\mathrm{mm} \mathrm{yr}^{-1}$. $\mathrm{AA}^{\prime}$ and $\mathrm{BB}^{\prime}$ are cross sections showing the depth distribution of relocated earthquakes [Engdahl et al., 1998]. PFS, Pampean flat slab segment; JFR, Juan Fernandez Ridge; EHB, Engdahl-(van der) HilstBuland.

[3] The aim of this paper is to investigate and compare the present-day and long-term, Neogene-Quaternary tectonic regimes in the Andean foreland of western Argentina $\left(29^{\circ} \mathrm{S}-33^{\circ} \mathrm{S}\right)$. The present-day tectonic regime is derived from inversion (deviatoric stress) and moment tensor sums (strain and seismic rate of deformation) of focal mechanism solutions of moderate to large earthquakes localized along the Chilean margin and in the Andean foreland. The results are compared to NUVEL-1 [DeMets et al., 1990, 1994], and to the new Global Positioning System (GPS)-derived velocity field for the Andes Mountains [e.g., Kendrick et al., 2003; Brooks et al., 2003]. The Neogene-Quaternary tectonic regime is based on inversion of fault plane data (deviatoric stress) and slip rates derived from geological data as well as cosmic ray exposure dating along selected active faults [e.g., Siame et al., 1997a, 1997b, 2002]. From this comparison, the Andean back arc of western Argentina can be regarded as an obliquely converging foreland where Plio-Quaternary deformations are partitioned between strike-slip and thrust motions that are localized on the east 
verging thin-skinned Argentine Precordillera and the west verging thick-skinned Pampean Ranges, respectively.

\section{Present-Day Tectonic Regime}

\subsection{Data and Studied Zones}

[4] To precise the present-day tectonic regime controlling the active deformation in the central Andes, the state of stress along the Chilean trench $\left(22^{\circ} \mathrm{S}-36^{\circ} \mathrm{S}\right)$ and within the Andean foreland of San Juan and Mendoza provinces $\left(29^{\circ} \mathrm{S}-33^{\circ} \mathrm{S}\right)$ have been examined using shallow (i.e., focal depth $<70 \mathrm{~km}$ ) moderate to large earthquakes (i.e., $M_{w} \geq$ 5.0) from Harvard University centroid moment tensor (CMT) catalog [e.g., Dziewonski et al., 1981]. This catalog includes the determination of the seismic moment and focal mechanism parameters for worldwide earthquakes of $M_{w} \geq$ 5.0 from 1977 to the present. The CMT solutions are in general good determination of various earthquake parameters, even if the CMT depth is often a fixed parameter, due to a poor azimuthal coverage of the worldwide station network, and thus not entirely reliable. Nevertheless, through a statistical review of accuracy of modern global earthquake catalogs, Kagan [2003] demonstrated that the CMT catalog appears to be the best data set in completeness and accuracy of its solutions. Bearing this inherent imprecision of hypocenter location in mind, Harvard CMT catalog has thus been used for this study. In the Andean foreland of San Juan, both teleseismic and local network data are available, allowing a comparison of the results obtained thanks to both data sets.

[5] Between $22^{\circ} \mathrm{S}$ and $36^{\circ} \mathrm{S}$, the central Andes can be divided into four zones. Considering the Nazca plate segmentation at intermediate depths, and the epicenter distribution of shallow, moderate to large earthquakes (Figure 2), three distinct zones can be distinguished along the Chilean trench and one zone in the sub-Andean domain: zone 1 $\left(22^{\circ} \mathrm{S}\right.$ to $28^{\circ} \mathrm{S}$ ) corresponds to $\mathrm{a} \sim 30^{\circ}$ dipping slab segment (hereinafter referred as steep slab segment); zone $2\left(28^{\circ} \mathrm{S}\right.$ to $33^{\circ} \mathrm{S}$ ) corresponds to the Pampean flat slab segment; zone 3 $\left(33^{\circ} \mathrm{S}-36^{\circ} \mathrm{S}\right)$ corresponds to the southward adjacent steep slab segment; and zone 4 is at about $31^{\circ} \mathrm{S}$ where the Andean foreland exhibits a high level of crustal seismicity (Figure 2). Within the three zones located along the Chilean trench, the selected seismic events are predominantly compressional, even if some normal faulting events characterize extensive mechanical readjustments within the subducted plate. Both steep slab segments (zones 1 and 3 ) are characterized by high seismic energy release with one $M_{w} 8.0$ event during the last 30 years (zone 1, 30 July 1995, $M_{w}$ 8.0; zone 3, 3 March 1985, $M_{w}$ 7.9), whereas the flat slab segment (zone 2) have not experienced any event with $M_{w}>7.1$ during the same period. Converse to the subduction zone, the Andean back arc region experienced low seismic moment release since 1977, except for the region around San Juan (Figures 1 and 2), where the earthquake catalog is largely dominated by the $M_{w}$ 7.4 that stroke this region in November 1977 [KadinskyCade and Reilinger, 1985]. Within the four previously defined zones, best fitting stress tensors and moment tensor sums of the focal mechanism data sets (1977-2003; i.e.,
26 years) were obtained using the methodologies presented in Appendix A.

\subsection{Inversions and Moment Tensor Sums Along the Chilean Trench}

[6] Within the three zones defined along the Chilean trench, the orientation of the compressional deviatoric stress axes $\left(\sigma_{1}\right)$ is striking about N83-84 ${ }^{\circ} \mathrm{E}$ (Table 1 and Figure 2) that is in the convergence direction between the Nazca and South American plates [DeMets et al., 1990, 1994; Kendrick et al., 2003]. Within zones 1 and $3, \sigma_{1}$ axes are eastwardly plunging roughly $20^{\circ}$, whereas it is only plunging $10^{\circ}$ within zone 2 where the slab is nearly horizontal at intermediate depths. Within the three zones, $\sigma_{3}$ axes are nearly vertical, ranging between $70^{\circ}$ and $80^{\circ}$ (Table 1 ). Interestingly, moment tensor sums give consistent results with $P$ axes striking in an E-W direction, relatively parallel to the computed $\sigma_{1}$ axes (Figure 2 and Table 1). All together, when compared to the relative movement between Nazca and South American plates (NUVEL-1 [DeMets et al., 1990, 1994]), or to the regional GPS-derived velocity field [Kendrick et al., 2003; Brooks et al., 2003], these results suggest that the slight convergence obliquity at the plate boundary is mostly accommodated within the subduction zone itself.

\subsection{Inversions and Moment Tensor Sums Within the Andean Foreland}

[7] Within the Andean foreland of western Argentina, earthquake activity is characterized by two depth distributions (Figure 3). Earthquakes with hypocentral depths at about $100 \mathrm{~km}$ show flat slab geometry of the Nazca plate beneath South America [Cahill and Isacks, 1992; Smalley et al., 1993; Engdahl et al., 1998], whereas earthquakes with hypocentral depth ranging from 5 to $35 \mathrm{~km}$ correspond to crustal seismicity between the Argentine Precordillera and the Sierras Pampeanas [Smalley et al., 1993]. In this region, the crustal seismicity pattern derived from Preliminary Determination Epicenter (PDE) catalog (U.S. Geological Survey National Earthquake Information Center) is dominated by the cluster of events centered on the Sierra Pie de Palo basement uplift (Figure 3). To efficiently interpret this pattern, we applied a gridding algorithm to the seismic event frequency distribution (Figure 3). To derive such a frequency grid from the PDE catalog, the cumulative number of events has been divided by the catalog time span (i.e., 30 years) within a grid composed by $100 \times 112$, 4-km-large cells and then interpolated using an inverse distance weighting (IDW) algorithm (Figure 3). The resulting map not only takes into account the dense north trending ellipsoid-shaped clustering of events centered on the eastern side of the Sierra Pie de Palo, but also clearly unveils two others areas of moderate frequency located near San Juan and Mendoza cities (Figure 3). Around San Juan city, this zone of moderate frequency corresponds to the Tulum and Matagusanos valleys, where thick-skinned active faulting has been suspected to be responsible for the $M_{s} 7.4,1944$ San Juan earthquake [Siame et al., 2002]. The rest of the Argentine Precordillera is relatively aseismic, particularly 

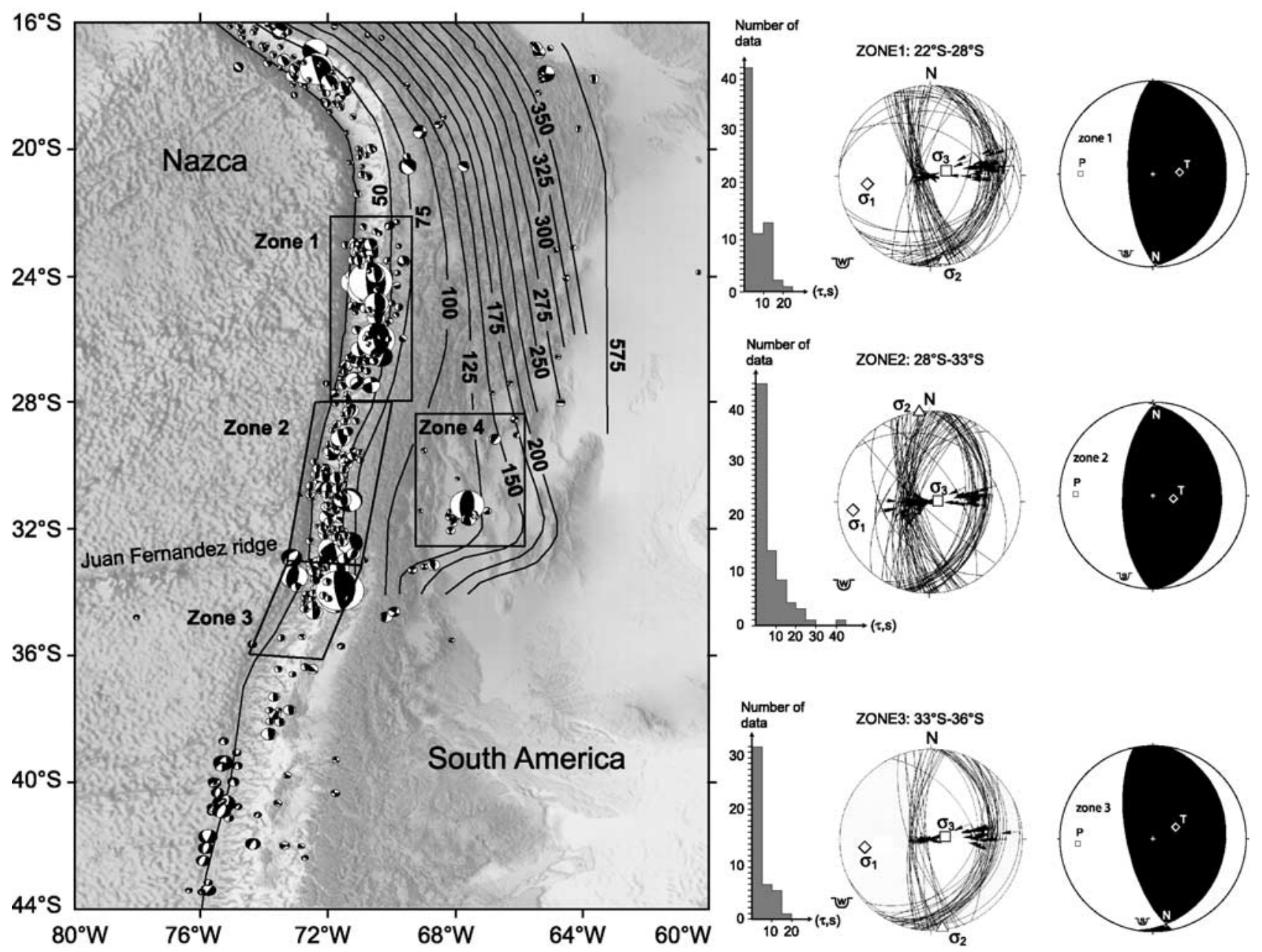

Figure 2. (left) Map of the central Andes between $16^{\circ} \mathrm{S}$ and $44^{\circ} \mathrm{S}$ latitude (globe shaded relief after Hastings and Dunbar [1998] and bathymetry after Smith and Sandwell [1997]) showing the focal mechanism solutions available in this Andean region from Harvard catalog (1977-2003, depth $\leq 70 \mathrm{~km}$, $M \geq 5.0$ ). Boxes locate the different zones, depicted along the Chilean trench and within the sub-Andean domain, where the inversion and moment tensor sum methodologies have been applied. (right) Lower hemisphere stereoplots (Wulf) and synthetic focal solutions (Schmidt) showing inversion and moment tensor sum results, respectively. Histograms show distribution of deviation angles between the selected $s$ and the predicted $\tau$ slip vector on each preferred seismic plane. Stress axes obtained by inversions are shown by diamonds $\left(\sigma_{1}\right)$, triangles $\left(\sigma_{2}\right)$, and squares $\left(\sigma_{3}\right)$. Strain axes obtained by summations are shown by squares $(P)$ and diamonds $(T)$.

north of the North Sierra Pie de Palo Fault (NPF) (Figure 3). This earthquake frequency pattern is in close agreement with epicenter distributions from local seismic networks [Régnier et al., 1992; Smalley et al., 1993], relocated teleseismic events [Engdahl and Villaseñor, 2002], and with the location of the regional active faults (Figure 3).

[8] Within the Andean foreland of San Juan, earthquakes with $M_{w} \geq 4.9$ provide evidence for predominantly reverse to strike-slip faulting (Figure 4), mostly indicate east trending shortening on $\sim 40^{\circ}$ dipping faults, and have their source depths ranging from 5 to $35 \mathrm{~km}$. From September 1987 to May 1988 [Régnier et al.,1992] operated a digitally recording seismic network that provided a detailed view of the crustal seismicity in the area (with a maximum activity at about $25 \mathrm{~km}$ depth). Even if both seismicity patterns observed from teleseismic and local data are quite similar, teleseismic data are centered on the low-lying valley between Sierra Pie de Palo and Sierra de la Huerta, whereas local data cluster below Sierra Pie de Palo (Figure 4). This slight difference in the epicenter location is most probably due to systematic differences in location obtained for the two data sets. Best fitting deviatoric stress tensors from inversions of both teleseismic and local data sets are consistent with $\sigma_{1}$ axes striking $\mathrm{N} 95 \pm 2^{\circ} \mathrm{E}$ (Table 1). Moment tensor sum of the CMT solutions provide consistent results with $P$ axes striking $\mathrm{N} 93^{\circ} \mathrm{E}$ (Table 1), parallel to the computed $\sigma_{1}$ axes. Both inversion and moment tensor sums indicates that $\sigma_{1}$ and $P$ axes are roughly orthogonal to 
Table 1. Inversion and Moment Tensor Sum Results for the Four Selected Zones ${ }^{\mathrm{a}}$

\begin{tabular}{|c|c|c|c|c|c|c|c|c|c|c|}
\hline & & & & & & & \multicolumn{4}{|c|}{ Zone 4} \\
\hline & \multicolumn{2}{|c|}{ Zone 1} & \multicolumn{2}{|c|}{ Zone 2} & \multicolumn{2}{|c|}{ Zone 3} & \multicolumn{2}{|c|}{ Teleseismic Data } & \multicolumn{2}{|c|}{ Local Data } \\
\hline & $\mathrm{azm}$ & $\mathrm{pl}$ & azm & $\mathrm{pl}$ & azm & $\mathrm{pl}$ & azm & $\mathrm{pl}$ & azm & $\mathrm{pl}$ \\
\hline Inversions & $83 \%$ & $R=0.49$ & $73 \%$ & $R=0.55$ & $81 \%$ & $R=0.49$ & $84 \%$ & $R=0.44$ & $33 \%$ & $R=0.28$ \\
\hline$\sigma_{1}$ & 263 & 21 & 264 & 10 & 263 & 18 & 93 & 0 & 277 & 2 \\
\hline$\sigma_{2}$ & 171 & 3 & 354 & 0 & 173 & 1 & 183 & 4 & 187 & 2 \\
\hline$\sigma_{3}$ & 74 & 69 & 84 & 80 & 78 & 72 & 357 & 86 & 46 & 87 \\
\hline Moment sums & $84 \%$ & $R=0.50$ & $75 \%$ & $R=0.50$ & $R=85 \%$ & $R=0.50$ & $84 \%$ & $R=0.50$ & NA & NA \\
\hline$P$ & 270 & 23 & 271 & 18 & 266 & 21 & 93 & 1 & NA & NA \\
\hline$N$ & 179 & 2 & 2 & 25 & 173 & 8 & 183 & 1 & NA & NA \\
\hline \multirow[t]{4}{*}{$T$} & 85 & 67 & 97 & 72 & 62 & 68 & 295 & 89 & NA & NA \\
\hline & & & & & & & & & & \\
\hline & & & & & & & & & & Data \\
\hline & \multicolumn{2}{|c|}{ Zone 1} & \multicolumn{2}{|c|}{ Zone 2} & \multicolumn{2}{|c|}{ Zone 3} & \multicolumn{2}{|c|}{ Teleseismic Data } & azm & $\mathrm{pl}$ \\
\hline $\mathrm{m}_{\mathrm{P}}, \mathrm{N} \mathrm{m}$ & \multicolumn{2}{|c|}{$-2.0 \mathrm{E}+21$} & \multicolumn{2}{|c|}{$-1.1 \mathrm{E}+20$} & \multicolumn{2}{|c|}{$-1.1 \mathrm{E}+21$} & \multicolumn{2}{|c|}{$-1.91 \mathrm{E}+20$} & NA & NA \\
\hline $\mathrm{m}_{\mathrm{N}}, \mathrm{N} \mathrm{m}$ & \multicolumn{2}{|c|}{$-2.3 \mathrm{E}+17$} & \multicolumn{2}{|c|}{$6.4 \mathrm{E}+17$} & \multicolumn{2}{|c|}{$5.9 \mathrm{E}+17$} & \multicolumn{2}{|c|}{$1.10 \mathrm{E}+18$} & NA & NA \\
\hline $\mathrm{m}_{\mathrm{T}}, \mathrm{N} \mathrm{m}$ & \multicolumn{2}{|c|}{$2.0 \mathrm{E}+21$} & \multicolumn{2}{|c|}{$1.1 \mathrm{E}+20$} & \multicolumn{2}{|c|}{$1.1 \mathrm{E}+21$} & \multicolumn{2}{|c|}{$1.90 \mathrm{E}+20$} & NA & NA \\
\hline Scalar $\mathrm{M}_{0}, \mathrm{~N}$ m & \multicolumn{2}{|c|}{$2.0 \mathrm{E}+21$} & \multicolumn{2}{|c|}{$1.1 \mathrm{E}+20$} & \multicolumn{2}{|c|}{$1.1 \mathrm{E}+21$} & \multicolumn{2}{|c|}{$1.9 \mathrm{E}+20$} & NA & NA \\
\hline
\end{tabular}

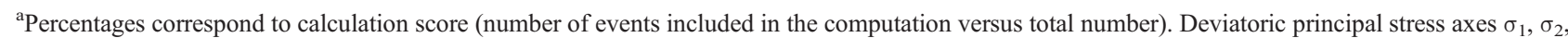
$\sigma_{3}$ are the compressional, intermediate, and extensional deviatoric stress axes, respectively. They are specified by azimuths (azm) measured clockwise from the north. Plunges $(\mathrm{pl})$ are measured from horizontal. $R=\left(\sigma_{2}-\sigma_{1}\right) /\left(\sigma_{3}-\sigma_{1}\right)$ is the stress ratio of the deviatoric stress tensor. $P, N$, and $T$ axes are the compressional, neutral, and tensional principal axes of the moment tensor. The orientation of these axes coincides with the orientation of the eigenvectors of the moment tensor. $\mathrm{P}$ coincides with the eigenvector with the smallest value (i.e., $\mathrm{m}_{\mathrm{P}}$ ), $N$ coincides with the eigenvector with the intermediate value (i.e., $\mathrm{m}_{\mathrm{N}}$ ), and $T$ coincides with the eigenvector with the largest value (i.e., $\mathrm{m}_{\mathrm{T}}$ ). NA, not available. Read $-2.0 \mathrm{E}+21$ as $-2.0 \times 10^{21}$.

the strike of the reverse faults that borders the Sierra Pie de Palo basement uplift, and consequently slightly rotated clockwise with respect to the Nazca versus South American plates convergence trend (Figure 4). When compared to the GPS-derived velocity field for the Andean Mountains [Kendrick et al., 2003; Brooks et al., 2003], it seems that this clockwise rotation of the stress axes not only results from local boundary effects within the Sierras Pampeanas, as already suggested by Régnier et al. [1992], but may have a more regional significance (see below).

\subsection{Seismic Rates of Deformation}

[9] Earthquake moment tensor sums can be used to investigate the seismic contribution of moderate to large earthquakes in regions of ongoing deformation [Jackson and McKenzie, 1988; Jost and Herrmann, 1989; Molnar and Ghose, 2000]. Along the Chilean margin, Brune's [1968] method allows to estimate the cumulative slip by summing the seismic moments of earthquakes causing slip on the subduction plane (see Appendix A). At shallow depth $(<70 \mathrm{~km})$, the three selected slab segments are dipping $25^{\circ}-30^{\circ}$ [Engdahl et al., 1998]. Using selected data from large interplate earthquakes, previous studies have estimated a maximum depth of seismic coupling along the Chilean trench ranging from 50 to $60 \mathrm{~km}$ [Tichelaar and Ruff, 1991; Pacheco et al., 1990; Súarez and Comte, 1993]. To estimate the seismic rates of deformation due to shallow earthquakes that characterize the three selected slab segments, scalar values of the seismic moment tensor sums have been normalized with respect to the slab segment lengths, using geometries with $25^{\circ}-30^{\circ}$ dipping slabs and maximum depth of seismic coupling ranging between 50 and $60 \mathrm{~km}$ (Table 2).

[10] Concerning the three zones defined along the Chilean margin, strong differences can be evidenced when comparing the flat slab segment with the two other steep slabs (Table 2). Indeed, both steep slabs exhibits normalized cumulative slips of about $0.4-0.5 \mathrm{~m}$, which are at least one order of magnitude greater than the averaged cumulative slip estimated for the flat slab segment (Table 2). Seismic strain rates can be deduced from these normalized cumulative slips when divided by the catalog time window (Table 2). Both steep slab segments are characterized by seismic strain rate of about $1.4-2.0 \mathrm{~cm} \mathrm{yr}^{-1}$, which correspond roughly to $22-31 \%$ and $16-23 \%$ of the GPS-derived and NUVEL-1 plate convergence rates, respectively (Table 2). Concerning the flat slab segment, it appears that the estimated seismic rate of deformation corresponds to less than $2 \%$ of the GPS-derived and NUVEL-1 plate convergence rates (Table 2).

[11] Within the Andean foreland of San Juan, available focal mechanism solutions also allow to calculate a seismic strain rate. Converse to the segments located along the trench, the Andean foreland region is an intraplate domain; where it is more appropriate to use Kostrov's [1974] approach (see Appendix A), which considers that the seismic energy is not released on a single fault but on several planes with different orientation distributed within a specific volume. In the foreland domain of San Juan, large to moderate earthquakes are mostly located within an area 

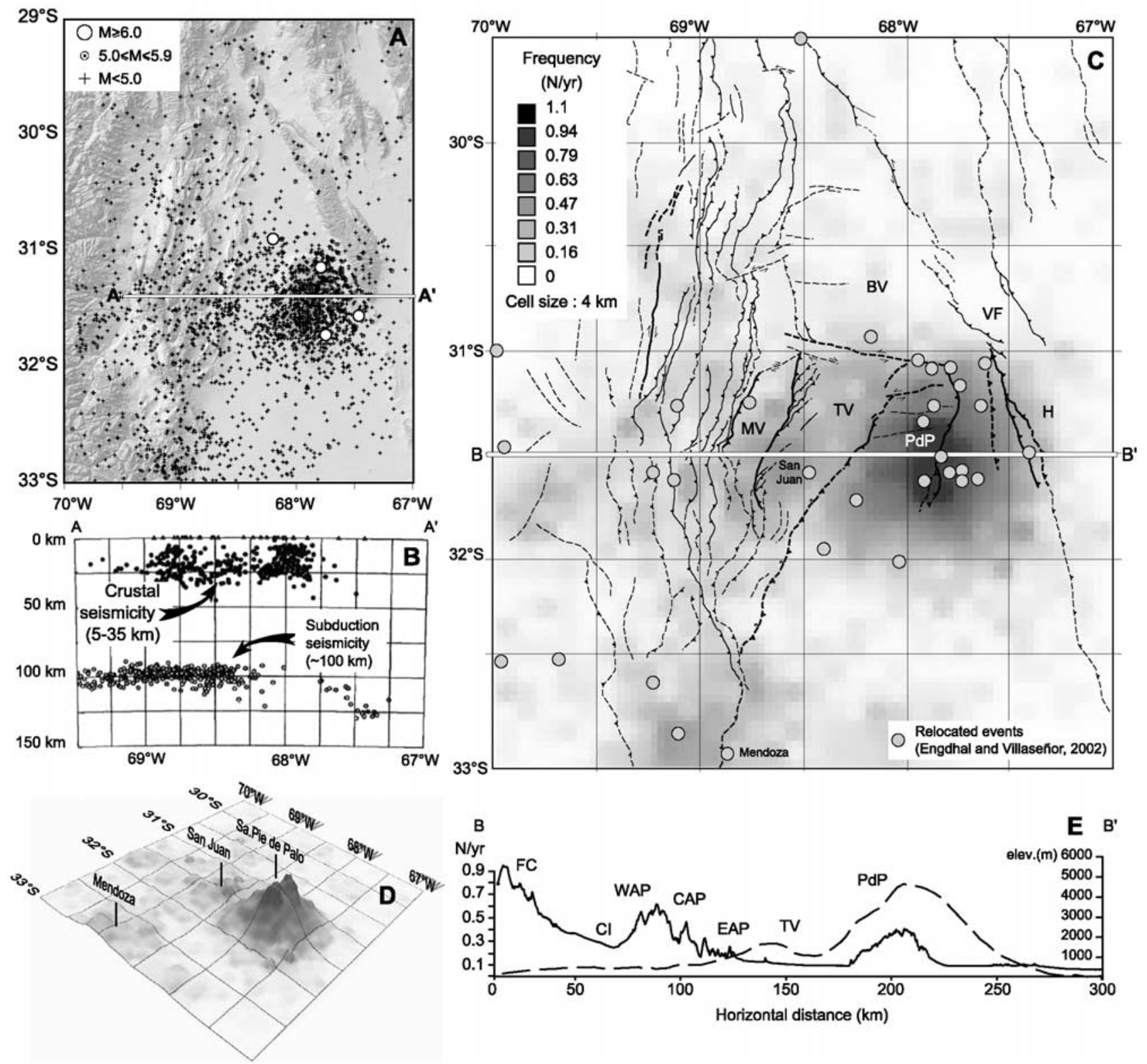

Figure 3. (a) Map of San Juan region (shaded relief from SRTM90 digital topography [e.g., Rosen et al., 2000; Farr and Kobrick, 2000]) showing 1973-2003 crustal seismicity from NEIC preliminary determination epicenters and locating cross section $\mathrm{AA}^{\prime}$. (b) Cross section $\left(\mathrm{AA}^{\prime}\right)$ showing shallow (solid circles) and intermediate depth (open circles) earthquakes (modified after Smalley et al. [1993]). (c) Frequency grid derived from the PDE catalog $(100 \times 112$, 4-km-large cells) together with a map of the principal tectonic structures (dashed lines). Quaternary structures are mapped after Siame [1998] and Costa et al. [2000]) (black heavy lines). Circles show the epicenter distribution of relocated seismic event [Engdahl and Villaseñor, 2002]. (d) Three-dimensional view of the frequency grid derived from the PDE catalog showing the high peak of frequency centered on the Sierra Pie de Palo and two other peaks of moderate frequency centered on San Juan and Mendoza cities. (e) Topographic cross section (BB') together with a plot of the frequency grid at about $31^{\circ} \mathrm{S}$. BV, Bermejo valley; VF, Valle Fértil range; H, La Huerta range; TV, Tulum valley; MV, Matagusanos valley; PdP, Sierra Pie de Palo; FC, Frontal Cordillera; CI, Calingasta-Iglesia basin; WAP, western Argentine Precordillera; CAP, central Argentine Precordillera; EAP, eastern Argentine Precordillera. 


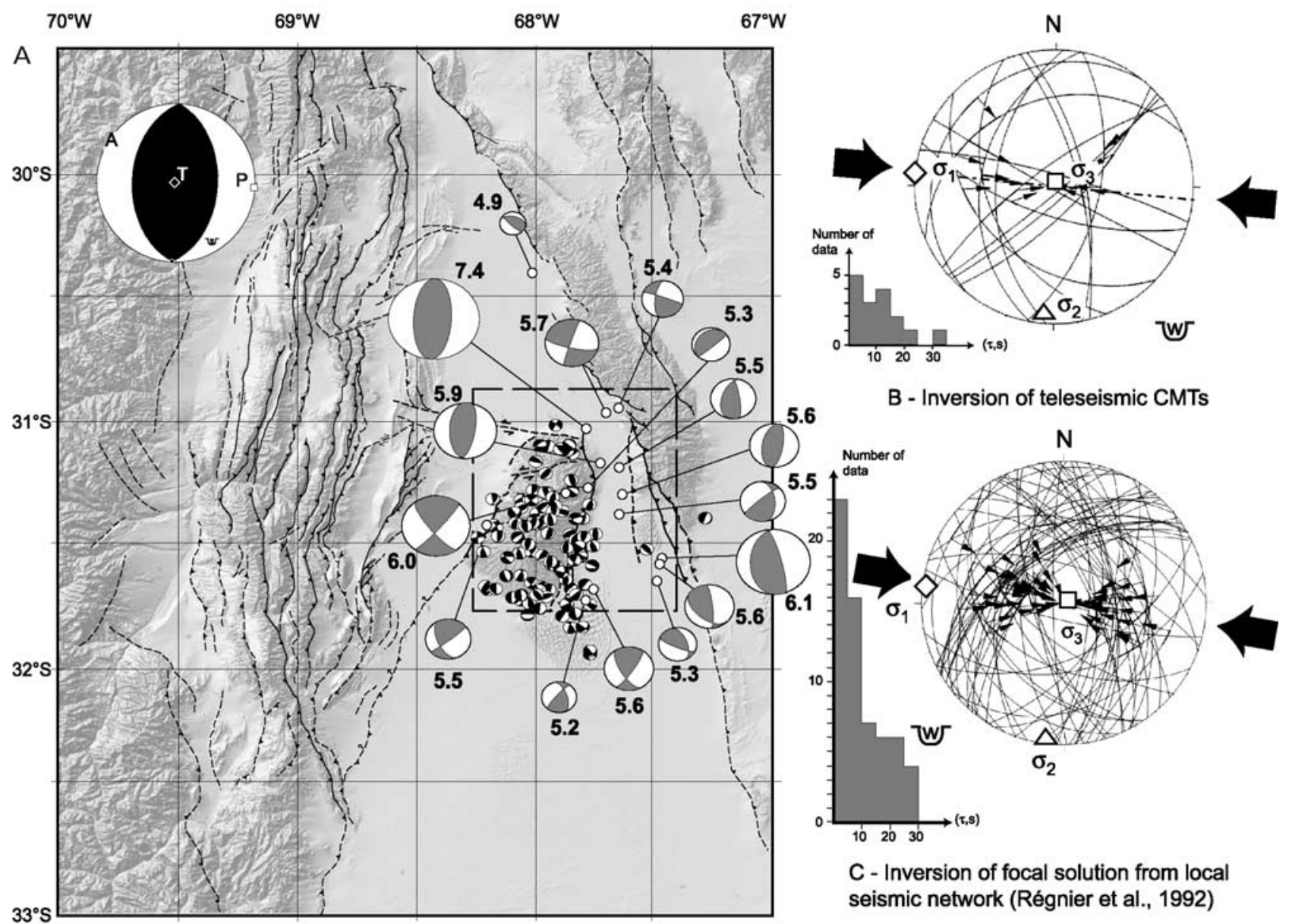

Figure 4. Map of the San Juan foreland domain (main tectonic structures over shaded SRTM90 digital topography [e.g., Rosen et al., 2000; Farr and Kobrick, 2000]) showing the location of the teleseismic (large grey beach balls; Harvard CMT catalog) and local (small black beach balls [Régnier et al., 1992]) focal mechanism solutions used in this study. Black numbers indicate Harvard CMT magnitudes. (a) Synthetic focal solution of the moment tensor sum using the Harvard CMT solution (lower hemisphere, Schmidt). (b) Lower hemisphere stereoplots (Wulf) showing inversion results for the teleseismic data set. (c) Lower hemisphere stereoplots (Wulf) showing inversion results for the local data set. Histograms show distribution of deviation angles between the selected $s$ and the predicted $\tau$ slip vector on each preferred seismic plane. Stress axes obtained by inversions are shown by diamonds $\left(\sigma_{1}\right)$, triangles $\left(\sigma_{2}\right)$, and squares $\left(\sigma_{3}\right)$.

of $123 \times 93 \mathrm{~km}^{2}$ (Figure 4). As previously reported above, this region is experiencing a high level of crustal seismicity, with a seismogenic depth ranging between 25 and $35 \mathrm{~km}$ [Régnier et al., 1992; Smalley et al., 1993]. Using these parameters to estimate the seismic volume of the deformed region, the moment tensor sum yields a seismic rate of $2.8-$ $4.0 \mathrm{~cm} \mathrm{yr}^{-1}$ (Table 2).

[12] Within the four zones, seismic strain rate estimates from moment tensor sums are minimal values since aseismic creeping, viscoelasticity deformation and contribution caused by earthquakes with magnitudes smaller than 5.0 are neglected. Even if the seismic moment tensor sum approach is strongly dependent on the time window of the catalog (only 26 years when compared to the subduction seismic cycle), it is striking that the estimated seismic rates of deformation are about the same for the steep slab segments, whereas it is one order of magnitude lower for the flat slab segment. When compared to the seismic strain rates estimated within the subduction zone associated with the two steep slab segments, it appears that the strain rate estimated for the San Juan foreland is slightly higher, but on the same order of magnitude.

[13] Even if one argued as to the degree to which the available time window is representative, the region has experienced 4 earthquakes with $M \sim 7$ during the last 60 year. Thus, considering one $M \sim 7$ in 26 years is probably realistic to address the seismic strain released in the San Juan Basin during the second half of the 20th century. 
Table 2a. Seismic Rates of Deformation Derived From Moment Tensor Sums ${ }^{\text {a }}$

\begin{tabular}{|c|c|c|c|c|}
\hline & Zone 1 & Zone 2 & Zone 3 & Zone 4 \\
\hline Length, km & 670 & 560 & 370 & \\
\hline Area, $\mathrm{km}^{2}$ & & & & $1.1 \mathrm{E}+04$ \\
\hline $25^{\circ} / 60 \mathrm{~km}$ & $9.5 \mathrm{E}+04$ & $8.0 \mathrm{E}+04$ & $5.3 \mathrm{E}+04$ & \\
\hline $30^{\circ} / 50 \mathrm{~km}$ & $6.7 \mathrm{E}+04$ & $5.6 \mathrm{E}+04$ & $3.7 \mathrm{E}+04$ & \\
\hline$\Sigma M_{0}, \mathrm{~N} \mathrm{~m}$ & $2.0 \mathrm{E}+21$ & $1.2 \mathrm{E}+20$ & $1.1 \mathrm{E}+21$ & $1.9 \mathrm{E}+20$ \\
\hline$M_{0}$ of the sum, $\mathrm{N} \mathrm{m}$ & $2.0 \mathrm{E}+21$ & $1.1 \mathrm{E}+20$ & $1.1 \mathrm{E}+21$ & $1.9 \mathrm{E}+20$ \\
\hline $\mathrm{CC}$ & 98 & 93 & 97 & 99 \\
\hline$\Sigma M_{0}(\mathrm{P}$ axis $), \mathrm{N} \mathrm{m}$ & $2.0 \mathrm{E}+21$ & $1.1 \mathrm{E}+20$ & $1.1 \mathrm{E}+21$ & $1.9 \mathrm{E}+20$ \\
\hline \multicolumn{5}{|l|}{$U, \mathrm{~m}$} \\
\hline $25^{\circ} / 60 \mathrm{~km}$ & 0.35 & 0.02 & 0.36 & \\
\hline $30^{\circ} / 50 \mathrm{~km}$ & 0.50 & 0.031 & 0.51 & \\
\hline \multicolumn{5}{|l|}{ Volume, $\mathrm{km}^{3}$} \\
\hline $35 \mathrm{~km}$ & & & & $4.0 \mathrm{E}+05$ \\
\hline $25 \mathrm{~km}$ & & & & $2.9 \mathrm{E}+05$ \\
\hline \multicolumn{5}{|l|}{$\dot{\varepsilon}_{i j \operatorname{Hmax}}, \mathrm{yr}^{-1}$} \\
\hline $35 \mathrm{~km}$ & & & & $3 \mathrm{E}-07$ \\
\hline $25 \mathrm{~km}$ & & & & $4 \mathrm{E}-07$ \\
\hline \multicolumn{5}{|l|}{ Seismic rate, $\mathrm{cm} \mathrm{yr}^{-1}$} \\
\hline $25^{\circ} / 60 \mathrm{~km}$ & 1.36 & 0.09 & 1.37 & \\
\hline $30^{\circ} / 50 \mathrm{~km}$ & 1.93 & 0.12 & 1.95 & \\
\hline $35 \mathrm{~km}$ & & & & 2.8 \\
\hline $25 \mathrm{~km}$ & & & & 4.0 \\
\hline
\end{tabular}

${ }^{\mathrm{a}} \Sigma \mathrm{M}_{0}$ is sum of the moment scalar values; $\mathrm{CC}$ is coherence criterion [Frohlich and Apperson, 1992]; $U$ is cumulated slip normalized to the length of the trench; $\dot{\varepsilon}_{i j}$ Hmax is horizontal component of the maximum compressional strain rate [Kostrov, 1974].

Indeed, this high shortening rate, combined with the historical seismicity, suggests that the San Juan region may have experienced a major cluster of events during the last century.

\section{Neogene to Quaternary Tectonic Regime}

\subsection{Structural Overview of the Andean Foreland of San Juan $\left(29^{\circ} \mathrm{S}-33^{\circ} \mathrm{S}\right)$}

[14] Between $29^{\circ} \mathrm{S}$ and $33^{\circ} \mathrm{S}$ latitude, the Andean foreland of San Juan and Mendoza provinces is characterized by three major north trending mountainous ranges: The Main Cordillera, the Argentine Frontal Cordillera (FC), the Argentine Precordillera (AP), and the Sierras Pampeanas (SP) (Figure 5). The Main Cordillera was the first morphostructural unit developed after the Farallones plate breakup and is closely related to the shifting of the Andean orogenic front ever since. The associated mountain building processes ended while the Andean shortening was taking place in the FC and AP. The AP mountain belt, which is nearly $400 \mathrm{~km}$ long and roughly $80 \mathrm{~km}$ wide, is a thrust-and-fold belt separated from the FC by an N-S piggyback basin: the Calingasta-Iglesia Valley (Figure 5). To the east, the AP is flanked by the Bermejo foreland basin that separates the AP thrust belt from the SP, a structural province characterized by ranges uplifted above moderate to highly dipping, mostly west verging reverse faults that root deeply into the Precambrian basement rocks [Ramos et al., 2002]. The structural evolution of this region reflects the regional convergence between the Nazca and South America plates, which led to the formation of the east verging thin-skinned AP and of the west verging thick-skinned SP, forming two opposite verging structural systems (Figure 5) [Jordan et al., 1993; Zapata and Allmendinger, 1996].

[15] The Frontal Cordillera is the major Andean topographic feature in the studied region, and reaches elevation higher than $5000 \mathrm{~m}$. This mountain belt is mainly composed of a thick Carboniferous to Triassic volcanic rocks and batholiths [Llambias and Caminos, 1987], as well as significant Lower and Middle Miocene volcanic rocks [Ramos et al., 1986]. During the Andean deformation, the FC has apparently behaved as relatively rigid blocks, disrupted by high-angle reverse faults. Allmendinger et al. [1990] suggested that between $29^{\circ}$ and $31^{\circ} \mathrm{S}$ latitude, the Frontal Cordillera is uplifted as a ramp anticline over a midcrustal décollement.

[16] The 30-km-wide Calingasta-Iglesia Valley is a piggyback basin partly filled with Mio-Pliocene sediments and andesites, and Quaternary deposits [Beer et al., 1990]. The Quaternary sediments are mainly related to Pleistocene to Holocene alluvial fans [Siame et al., 1997a]. In this basin, the continental strata deposited from $\sim 16 \mathrm{Ma}$ to at least 6 Ma [Beer et al., 1990], while crustal shortening was occurring in the FC and AP. This basin has been interpreted to have been passively transported above a horizontal décollement that links midcrustal deformation beneath the FC with the thin-skinned tectonics in the AP [Beer et al., 1990]. In the Iglesia valley, the El Tigre Fault (ETF) is a $120-\mathrm{km}$-long right-lateral strike-slip fault along which geomorphic features (fan and river offsets, sag ponds) and surface disruptions provide evidences for its Quaternary activity [Bastias, 1985; Siame et al., 1997b; Costa et al., 2000, and references herein].

[17] The Argentine Precordillera is classically divided into three structural provinces: western, central, and eastern [Ortíz and Zambrano, 1981; Baldis et al., 1982]. Western and central AP correspond to a mountainous topography predominantly characterized by a landscape of linear ranges and basins (Figure 5). Reverse thrust faults bound Paleozoic ranges and narrow linear valleys filled with Neogene and Quaternary continental sediments [von Gosen, 1992; Jordan et al., 1993]. Western and central AP have been described as a typical thin-skinned thrust-and-fold belt due to Neogene crustal shortening on west dipping, imbricated structures that root down to a 10-15 $\mathrm{km}$ deep main décollement [Allmendinger et al., 1990; von Gosen, 1992; Jordan et al., 1993; Cristallini and Ramos, 2000] (Figure 5). The eastern AP was formerly grouped in the AP because of its geo-

Table 2b. Comparison to NUVEL-1 and GPS-Derived Velocity Fields

\begin{tabular}{lcccc}
\hline & Zone 1 & Zone 2 & Zone 3 & Zone 4 \\
\hline NUVEL-1, \% & & & & \\
$25^{\circ} / 60 \mathrm{~km}$ & 16.3 & 1.0 & 16.2 & 47.4 \\
$30^{\circ} / 50 \mathrm{~km}$ & 23.1 & 1.4 & 23.1 & 33.9 \\
GPS $\%$ & & & & \\
$25^{\circ} / 60 \mathrm{~km}$ & 21.6 & 1.4 & 21.7 & 62.9 \\
$30^{\circ} / 50 \mathrm{~km}$ & 30.7 & 1.9 & 30.9 & 44.9 \\
\hline
\end{tabular}



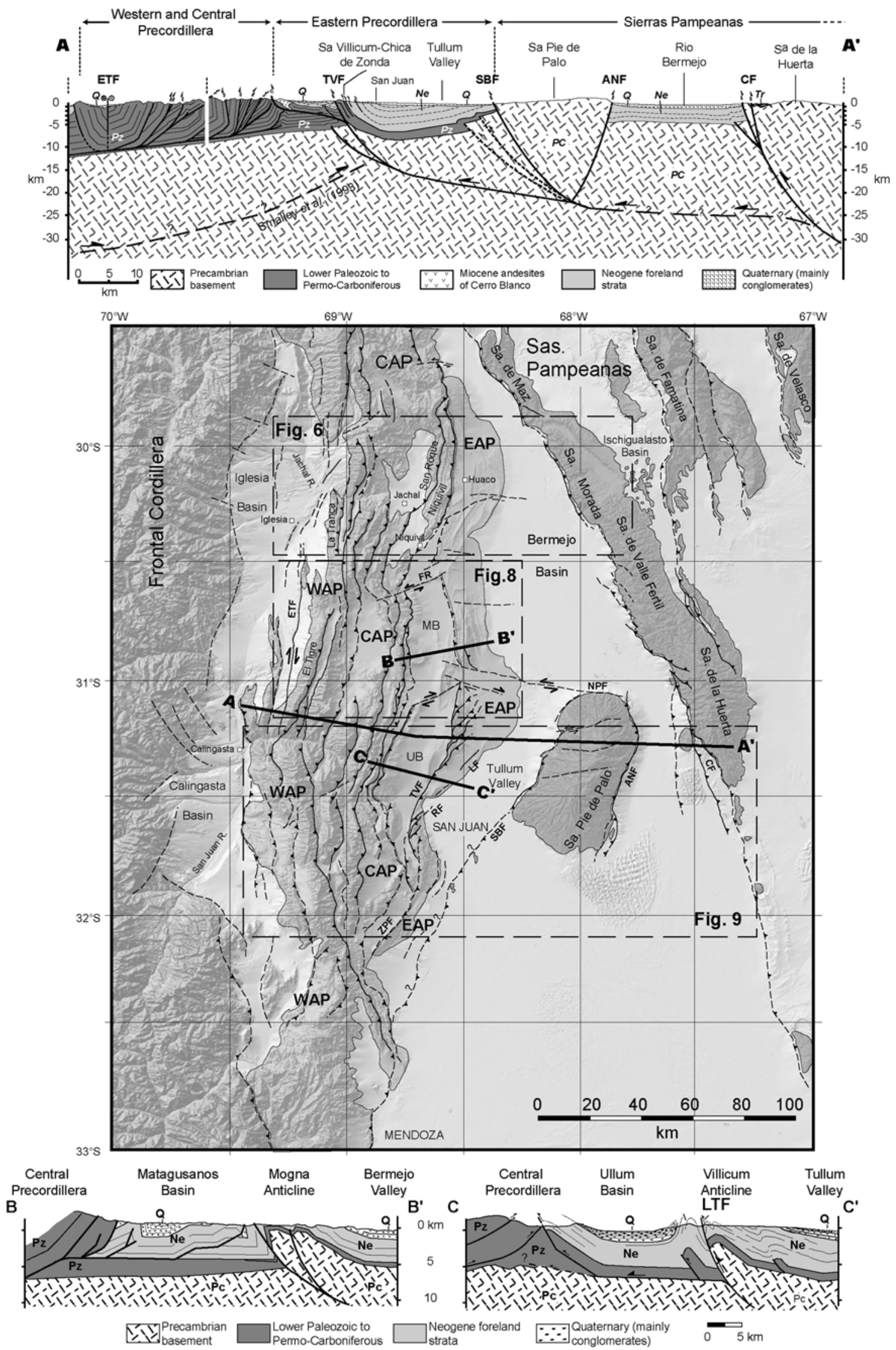

Figure 5 
graphic proximity and mostly from Paleozoic characteristics [Ortiz and Zambrano, 1981; Baldis et al., 1982]. Nevertheless, as it is thrusted westwardly from the craton thanks to faults that reach midcrustal depths, it has to be attributed to the SP domain [Zapata and Allmendinger, 1996; Jordan et al., 2001; Siame et al., 2002]. The central and eastern AP thus form oppositely verging thrust systems on the western and eastern side of the Ullúm-Matagusanos-Huaco valleys (Figure 5). Converse to the western and central AP, the eastern AP exhibits a drastic along-strike change of structural and geomorphic style at about $31^{\circ} \mathrm{S}$ latitude (Figure 5). North of this latitude, the eastern AP is characterized by thickskinned, blind thrusts and folds developed within the Neogene strata of the Bermejo valley [Zapata and Allmendinger, 1996], whereas it is marked by thick-skinned emergent thrusts carrying mostly Paleozoic rocks to the south [Smalley et al., 1993; Siame et al., 2002]. The location of this change in the structural style of the eastern AP coincides with the North Pie de Palo Fault. In fact, it is most probably related to a major change in the basement depth from 8 to $17 \mathrm{~km}$ across the southern margin of the Bermejo basin [Jordan and Allmendinger, 1986; Smalley et al., 1993]. South of $31^{\circ} \mathrm{S}$ latitude, the eastern AP is bounded by one regional active thrust, the Villicúm-Pedernal thrust [Costa et al., 2000, and references herein; Siame et al., 2002]. This thrust system corresponds to a $145-\mathrm{km}-\mathrm{long}, \mathrm{N} 20^{\circ} \mathrm{E}$ trending fault that runs on the western piedmont of the eastern AP bounding Sierra de Villicúm, Sierra Chica de Zonda, and Sierra de Pedernal (Figure 5). It is characterized by a surface fault trace that clearly displaces the Quaternary deposit surfaces [Siame et al., 2002].

[18] The Bermejo basin is a Miocene to recent foreland basin formed during the development of the Andes and Sierras Pampeanas mountains [Jordan et al., 2001]. It developed first between 20 and $\sim 7.3 \mathrm{Ma}$ as a simple foreland basin adjacent to the advancing thrusts of the western and central AP [Jordan et al., 2001]. Then after a short period ( $<1 \mathrm{Myr}$ ) of symmetrical foreland, it developed during the last 6.5 Myr as an asymmetrical foreland associated with both thin-skinned thrusting in the central AP and thick-skinned tectonics in the Pampean basement [Jordan et al., 2001].

[19] The Sierras Pampeanas are approximately north trending basement block uplifts of Precambrian metamorphic rocks [Caminos et al., 1982] with topographic characteristics that consist of steep sloped sides on the faulted front and gently dipping back sides (Figure 5). The topo- graphical back side corresponds to a Late Paleozoic erosional basement surface [Carignano et al., 1999; Costa et al., 2000]). The basement blocks are separated by wide, shallow basins of unmetamorphosed, relatively undeformed Carboniferous and younger sediments [Salfity and Gorustovich, 1984].

\subsection{States of Stress From Fault-Slip Vectors Inversion}

[20] In order to determine the most recent states of stress within the AP and westernmost SP, quantitative inversions of fault slip vectors (striae) measured at individual sites (see Table 3) have been computed using the nonlinear simplex method initially proposed by Carey [1979] (see Appendix A). Fault/striae have been measured in Paleozoic rocks from the AP, in Mesozoic rocks from the SP, and in Neogene to Quaternary continental deposits that fill the intermountainous and foreland basins. Some individual sites of measurements are also located on active faults where the computed states of stress can be regarded as significant for recent stress regimes.

[21] Even if, at individual sites, some of the observed fault slip data can be related to earlier stress states (e.g., Triassic extension in the SP), chronological relationships allowed determining the most recent set of fault slip vectors to determine the most recent states of stress which are discussed. The stress tensors determined using fault slip measurements within Paleozoic and Mesozoic rocks from the AP and SP are remarkably consistent with the stress tensors deduced from inversion of fault slip data collected within the Neogene and Quaternary sediments. Compared at a regional scale, the stress regimes determined at individual sites yield a regional stress pattern that is in close agreement with the stress tensors determined using local and teleseismic focal mechanism solutions, as well as with the elastic strain field deduced from the GPS-derived velocity field [e.g., Brooks et al., 2003].

\subsubsection{Stress Tensor Results for the Western Argentine Precordillera at $30^{\circ} \mathrm{S}$}

[22] At about $30^{\circ} \mathrm{S}$, inversion of fault slip data measured in Lower Paleozoic rocks within the Cuesta del Viento range (Cv1, Figure 6), and synorogenic tertiary conglomerates (Cv2, Figure 6) filling the adjacent Tranca valley, indicate compressional stress regimes ( $\sigma_{3}$ axis vertical) with $\mathrm{N} 70^{\circ} \mathrm{E}$ trending $\sigma_{1}$ axes $(\mathrm{Cv}$, Figure 7$)$ ). With a $R$ ratio close to zero $\left(\sigma_{1} \approx \sigma_{2}\right)$, the stress tensor computed for the fault striæ measured within the Paleozoic rocks is less constrained than that computed for the synorogenic conglom-

Figure 5. Structural regional map of Argentine Precordillera and western Sierras Pampeanas from SPOT and Landsat image analysis. It shows main structural sub provinces and locates the major regional structures (dotted lines refer to either inferred or buried faults). (top) Schematic regional cross section ( $\mathrm{AA}^{\prime}$ ) at about $31^{\circ} 30^{\prime} \mathrm{S}$ latitude showing thick-skinned deformation front (Western Precordillera is modified after Cristallini and Ramos [2000]; central Precordillera is modified after von Gosen [1992]; Eastern Precordillera is modified after Zapata and Allmendinger [1996] and Siame et al. [2002]). (bottom) Schematic cross sections ( $\mathrm{BB}^{\prime}$ is modified after Zapata and Allmendinger [1996]; CC' is after Siame et al. [2002]) showing the geometry at shallow depth of the interaction between east verging, thin-skinned and west verging, thickskinned tectonics. WAP, western Argentine Precordillera; CAP, central Argentine Precordillera; EAP, eastern Argentine Precordillera; ETF, El Tigre Fault; FR, Francia ramp; MB, Matagusanos Basin; UB, Ullúm Basin; NPF: North Pie de Palo Fault; TVF, Tapias-Villicúm Fault; LF, La Laja Fault; RF, Rinconada Fault; CF, Las Chacras Fault; SBF, Salinas-Berros Fault; ANF, Ampacama-Niquizanga Fault. Dotted boxes indicate locations of Figures 6, 8, and 9. 
Table 3. Inversion Results ${ }^{\mathrm{a}}$

\begin{tabular}{|c|c|c|c|c|c|c|c|c|c|c|c|c|c|c|c|}
\hline \multicolumn{2}{|l|}{ Site } & \multirow[b]{2}{*}{$N$} & \multicolumn{2}{|c|}{$\sigma_{1}$} & \multicolumn{2}{|c|}{$\sigma_{2}$} & \multicolumn{2}{|c|}{$\sigma_{3}$} & \multirow[b]{2}{*}{$R$} & \multirow[b]{2}{*}{ axever } & \multirow{2}{*}{$\begin{array}{c}N(\tau, s) \\
<20\end{array}$} & \multirow[b]{2}{*}{ MD } & \multirow[b]{2}{*}{ Rock Type } & \multirow{2}{*}{$\begin{array}{l}\text { Geological } \\
\text { Formation }\end{array}$} & \multirow[b]{2}{*}{ Age } \\
\hline Name & Code & & azm & $\mathrm{pl}$ & azm & $\mathrm{pl}$ & azm & $\mathrm{pl}$ & & & & & & & \\
\hline \multicolumn{16}{|c|}{ Western Precordillera } \\
\hline Cuesta del Viento1 & $\mathrm{Cv} 1$ & 12 & 248 & 12 & 340 & 11 & 110 & 74 & 0.37 & & 12 & 6.3 & basalt & Yerba Loca & Ordovician \\
\hline Cuesta del Viento2 & $\mathrm{Cv} 2$ & 27 & 72 & 12 & 340 & 10 & 210 & 74 & 0.04 & & 27 & 6.6 & conglomerate & Tranca & Miocene \\
\hline Sierra del Tigre & $\mathrm{Ti}$ & 26 & 268 & 1 & 178 & 6 & 11 & 84 & 0.53 & & 25 & 6.7 & sandstone & Yerba Loca & Ordovician \\
\hline La Punta & $\mathrm{Pu}$ & 7 & 87 & 0 & 177 & 1 & 356 & 89 & 0.97 & yes & 7 & 1.9 & dacite & Iglesia & Miocene \\
\hline Rio San Juan 4 & SJ4 & 7 & 81 & 16 & 350 & 1 & 255 & 74 & 0.76 & & 7 & 2.8 & conglomerate & Pachaco & Plio-Quaternary \\
\hline \multicolumn{16}{|c|}{ Central Precordillera } \\
\hline Rio San Juan 1 & SJ1 & 10 & 81 & 0 & 171 & 1 & 349 & 89 & 0.96 & yes & 10 & 17.8 & quartzite & La Dehessa & Carboniferous \\
\hline Rio San Juan 2 & SJ2 & 15 & 272 & 2 & 3 & 1 & 119 & 88 & 0.96 & & 14 & 25.9 & limestone & Talacasto & Devonian \\
\hline Rio San Juan 3 & SJ3 & 34 & 92 & 1 & 2 & 3 & 192 & 87 & 0.61 & & 26 & 3.4 & limestone & Punta Negra & Devonian \\
\hline Huaco 1 (I) & H1 & 10 & 317 & 6 & 48 & 1 & 152 & 84 & 0.87 & & 9 & 11.6 & conglomerate & Mogna Facies & Miocene \\
\hline Huaco 1 (II) & H1 & 10 & 85 & 0 & 175 & 0 & 342 & 90 & 0.73 & yes & 9 & 12.5 & conglomerate & Mogna Facies & Miocene \\
\hline Huaco 2 (I) & $\mathrm{H} 2$ & 15 & 146 & 0 & 56 & 0 & 306 & 90 & 0.48 & yes & 10 & 12.2 & volcanoclastic & Cerro Morado & Miocene \\
\hline Huaco 2 (II) & $\mathrm{H} 2$ & 8 & 75 & 20 & 342 & 8 & 230 & 68 & 0.08 & & 7 & 7.5 & volcanoclastic & Cerro Morado & Miocene \\
\hline Huaco 3 (I) & H3 & 5 & 123 & 0 & 213 & 0 & 352 & 90 & 0.81 & yes & 5 & 3.5 & limestone & San Juan & Ordovician \\
\hline Huaco 3 (II) & $\mathrm{H} 3$ & 16 & 94 & 0 & 184 & 1 & 359 & 89 & 0.93 & yes & 16 & 9.1 & limestone & San Juan & Ordovician \\
\hline Hucao 4 (I) & $\mathrm{H} 4$ & 6 & 134 & 14 & 225 & 2 & 324 & 76 & 0.06 & & 6 & 3.8 & limestone & San Juan & Ordovician \\
\hline Huaco 4 (II) & $\mathrm{H} 4$ & 12 & 247 & 4 & 157 & 12 & 357 & 77 & 0.88 & & 12 & 6.8 & limestone & San Juan & Ordovician \\
\hline Huaco 5 & H5 & 18 & 85 & 2 & 175 & 4 & 328 & 86 & 0.36 & & 17 & 9.5 & silt/sandstone & NA & Tertiary \\
\hline Huaco 6 (I) & H6 & 13 & 264 & 10 & 354 & 4 & 108 & 80 & 0.98 & & 13 & 10.2 & limestone & San Juan & Ordovician \\
\hline Huaco 6 (II) & H6 & 27 & 99 & 4 & 189 & 2 & 310 & 86 & 0.92 & & 26 & 4.2 & limestone & San Juan & Ordovician \\
\hline Tucunuco & $\mathrm{Tu}$ & 36 & 230 & 6 & 138 & 25 & 333 & 64 & 0.96 & & 33 & 11.2 & conglomerate & Upper Rio Jachal & Pliocene \\
\hline Matagusanos & Mat & 14 & 55 & 13 & 155 & 39 & 310 & 49 & 0.95 & & 14 & 6.4 & sandstone/conglomerate & Upper Rio Jachal & Pliocene \\
\hline Talacasto tertiary & Table & 18 & 88 & 19 & 358 & 2 & 261 & 70 & 0.18 & & 17 & 8.1 & silt/sandstone & Rio Paloma & Mio-Pliocene \\
\hline Talacasto thrust & Table & 17 & 268 & 12 & 360 & 8 & 123 & 75 & 0.44 & & 17 & 4.3 & limestone & San Juan & Ordovician \\
\hline Qda de la Burra & $\mathrm{Bu}$ & 10 & 95 & 4 & 3 & 25 & 194 & 64 & 0.78 & & 10 & 9.0 & silt & Cuculi & Miocene \\
\hline Los Pozos & Po & 25 & 258 & 5 & 167 & 9 & 21 & 79 & 0.76 & & 21 & 11.6 & conglomerate & Mogna & Plio-Quaternary \\
\hline \multicolumn{16}{|c|}{ Eastern Precordillera } \\
\hline Morado & Mo & 9 & 123 & 7 & 214 & 8 & 352 & 79 & 0.41 & & 9 & 10.0 & sandstone & Rio Salado & Miocene \\
\hline Villicum norte* & Vn & 9 & 286 & 10 & 17 & 7 & 141 & 78 & 0.53 & & 9 & 3.9 & silt/sandstone & Rio Salado & Miocene \\
\hline Villicum Sur* & Vs & 18 & 102 & 0 & 192 & 1 & 10 & 89 & 0.97 & & 17 & 15.6 & limestone & La Laja & Cambrian \\
\hline Las Tapias* & $\mathrm{Ta}$ & 47 & 120 & 3 & 30 & 2 & 260 & 86 & 0.49 & & 33 & 15.1 & silt/sandstone & Ullúm & Miocene \\
\hline La Laja* & $\mathrm{La}$ & 7 & 111 & 0 & 201 & 0 & 334 & 90 & 0.52 & yes & 7 & 5.4 & silt & Ullúm & Miocene \\
\hline Sa. Chica de Zonda* & Zo & 34 & 99 & 2 & 8 & 8 & 204 & 81 & 0.32 & & 24 & 14.8 & limestone & La Laja & Cambrian \\
\hline La Flecha & $\mathrm{F} 1$ & 12 & 302 & 6 & 211 & 6 & 78 & 82 & 0.74 & & 12 & 10.4 & silt/sandstone & $\mathrm{NA}$ & Tertiary \\
\hline \multicolumn{16}{|c|}{ Sierras Pampeanas } \\
\hline Marayes & Mar & 11 & 278 & 7 & 187 & 7 & 50 & 80 & 0.35 & & 11 & 8.7 & conglomerate & NA & Trias \\
\hline Las Chacras & $\mathrm{Ch}$ & 20 & 99 & 12 & 8 & 4 & 261 & 77 & 0.5 & & 20 & 8.9 & conglomerate & NA & Plio-Quaternary \\
\hline
\end{tabular}

${ }^{a}$ Results of stress tensor inversion from the geologically determined slip data along the Eastern Precordillera and in the Lomas de Las Tapias area. $N$ corresponds to the number of slip-data used for the inversions. Deviatoric principal stress axes $\sigma_{1}, \sigma_{2}$, and $\sigma_{3}$ are the compressional, intermediate, and extensional deviatoric stress axes, respectively. They are specified by azimuths (azm) measured clockwise from the north; plunge (pl) are measured from horizontal; $R=\left(\sigma_{2}-\sigma_{1}\right) /\left(\sigma_{3}-\sigma_{1}\right)$ is the stress ratio of the deviatoric stress tensor; $n(\tau, \mathrm{s})<20^{\circ}$ refers to the percentage of deviation angle lower than $20^{\circ}$; mean deviation angle is $\mathrm{MD}=\Sigma(\tau, s) / N$, where $(\tau, s)$ is the angle between the predicted slip vector, $\tau$, and the observed slip vector, $s$. Poorly distributed data sets have been analyzed with the additional assumptions that one of the stress axes is purely vertical (axever).

erates. This instability of the inversion may be interpreted as the result of fault striæ heterogeneity, either triggered by mixing of slip vectors from early and late faulting stages that we were unable to discriminate, or by block rotation during movement on the Tranca thrust. Following Jordan et al. [1993], early phase of western AP shortening started at roughly $20 \mathrm{Ma}$, followed by several million years of quiescence. At La Tranca range, geometrical relationships between the conglomerates, Paleozoic strata and the Tranca thrust indicate that most displacement is contemporaneous to the synorogenic conglomerates of the Tranca Valley, dated $19.5 \pm 1.1 \mathrm{Ma}$ [Jordan et al., 1993]. The stress state computed at La Tranca should thus be related to the earlier phase of shortening within the western AP. Nevertheless, the Tranca thrust might have been reactivated $\sim 8-9 \mathrm{Ma}$, and with large uncertainties, during the period covering $14-$ $1 \mathrm{Ma}$ [Jordan et al., 2001].

[23] Roughly $50 \mathrm{~km}$ farther south, the Tranca range disappears where the Sierra del Tigre constitutes the westernmost range of the AP (Figure 7). In this part of the western AP, fault slip data have been measured in Ordovician schists and sandstones from the Yerba Loca Formation (Ti, Figure 7), and within a dacite body at La Punta $(\mathrm{Pu}$, Figure 7), interbedded within the Neogene of the Iglesia basin dated at 16-6 Ma [Beer et al., 1990]. Both sites exhibit consistent reverse-faulting stress regimes with 


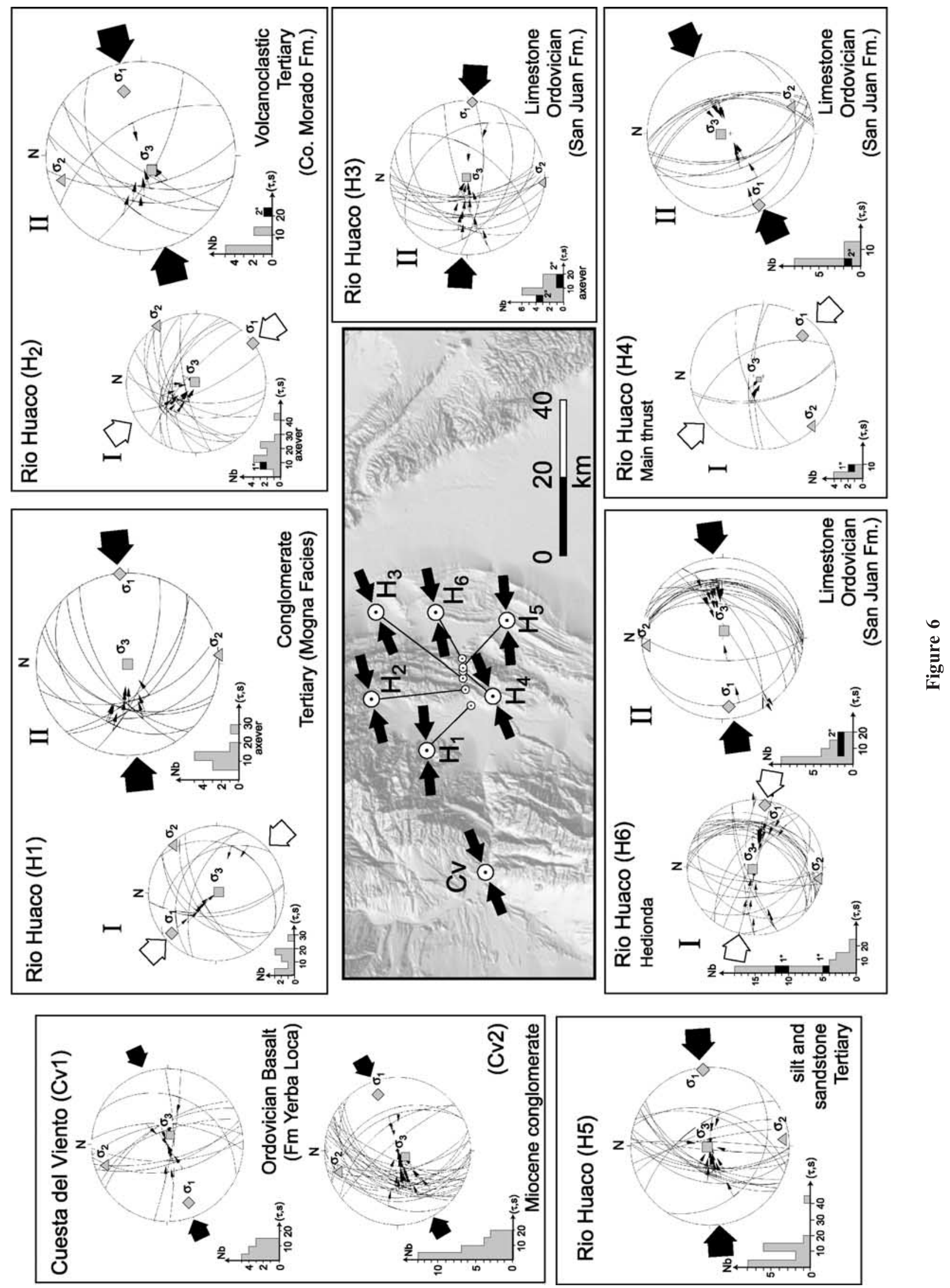


$\mathrm{N} 90^{\circ} \mathrm{E}$ trending $\sigma_{1}$ axes (Figures 6, 8, and 9 and Table 3) that can thus be related to a stress state younger than the dacite body.

\subsubsection{Stress Tensor Results for the Central AP at $30^{\circ} \mathrm{S}$ (Huaco Section)}

[24] At about $30^{\circ} \mathrm{S}$, the central AP is composed of the San Roque and Niquivil thrust sheets where five measurement sites are available, hereafter referred as the Huaco section (Figures 6 and 7). The San Roque thrust sheet is composed of a homoclinal sequence of Paleozoic units. The San Roque thrust itself is sealed by Quaternary alluvial deposits with no evidence of recent displacement [Zapata and Allmendinger, 1996]. Within the San Roque thrust sheet, two sites $\left(\mathrm{H}_{1}, \mathrm{H}_{2}\right.$, Figure 7) are located on the back limb of the San Roque thrust sheet, two other sites $\left(\mathrm{H}_{3}, \mathrm{H}_{4}\right.$, Figure 7) have been measured within the Cambro-Ordovician limestones that constitute the core of the San Roque thrust sheet, one site $\left(\mathrm{H}_{5}\right.$, Figure 7$)$ is located within the Tertiary strata that are overthrusted by the San Roque thrust sheet. The Niquivil thrust is the easternmost fault of the central AP. Its geometry evolved northwardly along strike from a fault-bound homocline to a large, asymmetric, east verging anticline [Zapata and Allmendinger, 1996]. Toward its southern termination, the Niquivil thrust progressively transformed into an anticline that ends abruptly against the left-lateral La Francia ramp (Figure 5). One site of fault slip measurements is available for the Niquivil thrust sheet $\left(\mathrm{H}_{6}\right.$, Figure 7), and located in the broad, asymmetric east verging Agua Hedionda anticline.

[25] Along the Huaco section, fault slip inversions permit to determine compressional stress regimes evolving from early SE trending to late $\mathrm{N} 80^{\circ} \mathrm{E}$ trending $\sigma_{1}$ axes (Figures $6-$ 9 and Table 3 ). To the west of the Huaco section, synorogenic conglomerates lying unconformably on the Ordovician San Juan Limestone (Mogna faciès, 12.8 Ma [Jordan et al., 1993]) have been interpreted as active growth axial surface located on the back limb of the San Roque Thrust [Zapata and Allmendinger, 1996]. Within those conglomerates $\left(\mathrm{H}_{1}\right.$, Figures 6 and 7), two families of fault slip data have been measured thanks to slickenslides observed on individual clast faces. The first and second series of fault slip data are consistent with compressional stress regimes with $\sigma_{1}$ axes are trending $\mathrm{N} 140^{\circ} \mathrm{E}$, and $\mathrm{N} 85^{\circ} \mathrm{E}$, respectively. Even though no evidence of chronological relationships has been observed at this site, these two stress states are in close agreement with those computed from fault slip data collected in the adjacent volcanoclastic strata from the Cerro Morado formation ( 13.4 Ma [Jordan et al., 1993]). At this measurement site $\left(\mathrm{H}_{2}\right.$, Figures 6 and 7$)$, chronological relationships (crosscutting striae) indicate that the NE trending compression is postdated by the ENE trending one. Al- though heterogeneities due to clasts rotations, resulting in a low-quality discrimination of $\sigma_{1}$ axis respect to $\sigma_{2}$ axis ( $R$ ratio close to zero), inversions of fault slip data on the back limb of the San Roque thrust sheet are relatively consistent (Figure 6).

[26] Close to the San Roque thrust, the deformation is more penetrative, with well-developed fault gouges and dense imbrications of reverse faults rooting onto the main thrust. The fault slip data collected within the Ordovician San Juan Limestone $\left(\mathrm{H}_{3}\right.$, Figures 6 and 7) are generally slickenslides associated with calcite recrystallizations over bedding planes or small minor planes secant to the strata. Although heterogeneities due to block tilting close to the main thrust, yielding low-quality discrimination of $\sigma_{1}$ axis respect to $\sigma_{2}$ axis ( $\mathrm{R}$ ratio close to zero), inversions of fault slip data, and chronological relationships among two successive fault slip generations, indicate that a $\mathrm{N} 80^{\circ} \mathrm{E}$ trending compressional stress regime postdates an earlier NW trending compression (Figure 6).

[27] The San Roque and Niquivil ranges are separated by a narrow Tertiary basin filled by a sequence of alternating, silts, fine-grained sandstones, and conglomeratic red beds. Farther south, such Tertiary strata have been dated to be younger than $\sim 33 \mathrm{Ma}$ and older than the clastic deposits of Mogna faciès [Jordan et al., 1993]. Close to the San Roque thrust $\left(\mathrm{H}_{4}\right.$, Figures 6 and 7$)$, the Tertiary strata are vertical to overturned and affected by a series of reverse faults. Inversion of the fault slip data collected within the finegrained sandstones and conglomeratic beds yields a compressional stress regime characterized by a $\mathrm{N} 85^{\circ} \mathrm{E}$ trending $\sigma_{1}$ axis (Figure 6). Farther east, fault slip data have been measured within the San Juan Limestone constituting the forelimb of the Agua Hedionda anticline. Those observations are mainly relying on slickenslides associated with calcite recrystallizations showing unambiguous senses of displacement. Like in the San Roque thrust sheet, chronological relationships allowed discriminating between an early $\left(\mathrm{N} 100^{\circ} \mathrm{E}\right.$ trending $\sigma_{1}$ axis) and late $\left(\mathrm{N} 85^{\circ} \mathrm{E}\right.$ trending $\sigma_{1}$ axis) compressional stress regimes (Figure 6).

[28] Along the Huaco section, in spite of heterogeneities due to clasts rotations (conglomerates, breccia) or block tilting close to the thrusts, fault slip data inversions are well constrained, relatively stable, and coherent. Zapata and Allmendinger [1996] proposed a three-stage evolution of the San Roque and Niquivil thrust sheets that is in agreement with the observation of an early NW trending to late $\mathrm{N} 80^{\circ} \mathrm{E}$ trending compressional stress regimes. First motion of the Niquivil thrust took place after or simultaneously with the San Roque thrust at about $8.6 \mathrm{Ma}$ [Jordan et al., 1993]. This first stage of deformation, leading to the growth of the Agua Hedionda anticline as a fault propagation fold,

Figure 6. Lower hemisphere stereoplots (Wulf) of reverse faulting. Individual fault planes and measured slip vectors at each site are plotted, arrows on fault planes point in directions of horizontal azimuth of the slip vectors. Stress axes obtained by inversions are shown by diamonds $\left(\sigma_{1}\right)$, triangles $\left(\sigma_{2}\right)$, and squares $\left(\sigma_{3}\right)$. Histograms show distribution of deviation angles between measured $s$ and predicted $\tau$ slip vector on each fault plane. Large arrows outside stereoplots give azimuth of maximum horizontal stress $\left(\sigma_{1}\right)$. The term "axever" indicates where inversion is constrained with the additional assumption that $\sigma_{1}$ axis is vertical. I and II refer to early and late stress regimes, respectively, evidenced through chronological relationships of fault slip data (shown with black rectangles on the histograms). 


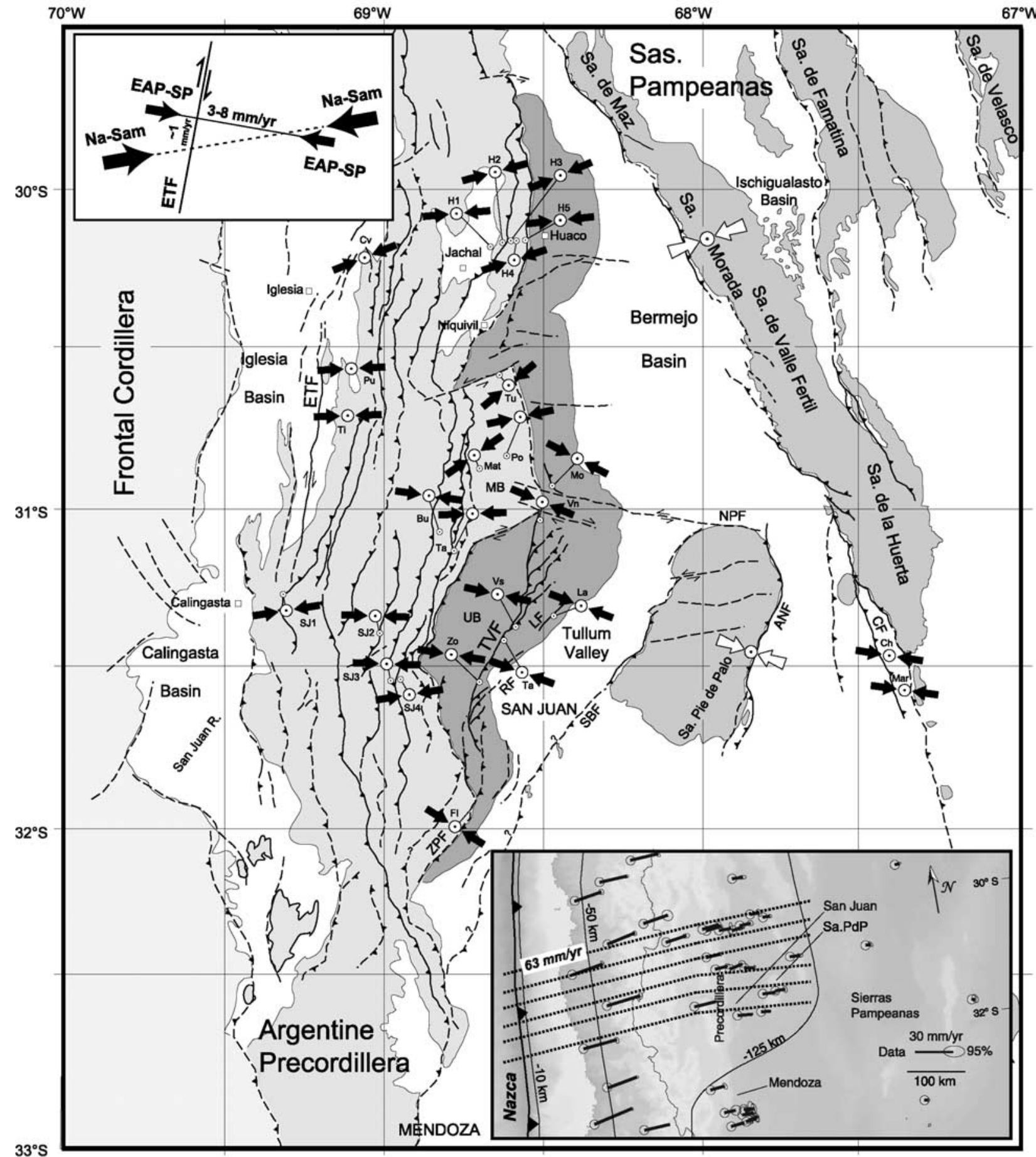

Figure 7. Structural regional map of Argentine Precordillera and western Sierras Pampeanas showing the inversion results of fault kinematic data measured at individual sites (black arrows indicate compressional direction). Cv, Cuesta del Viento; H1-H5, Huaco section; Pu, La Punta; Ti, Sierra del Tigre; Tu, Tucunuco; Po, Los Pozos; Mat, Matagusanos anticline; Mo; Cerro Morado; Vn, Villicúm norte; Vs, Villicúm sur; La, La Laja; Ta, Las Tapias; Zo, Sierra Chica de Zonda; SJ1-SJ4, Rio San Juan section; Fl, Quebrada la Flecha; Mar, Marayes; Ch, Las Chacras. White arrow (compressional direction) on Pie de Palo shows the inversion result for focal mechanism solutions. White arrow (compressional direction) on Sierra Morada shows the compressional direction inferred from regional observations (see text and Figure 10). Top inset depicts the Plio-Quaternary strain partitioning model for the San Juan foreland domain; bottom inset shows the GPS-derived velocity field (modified after Brooks et al. [2003]). 


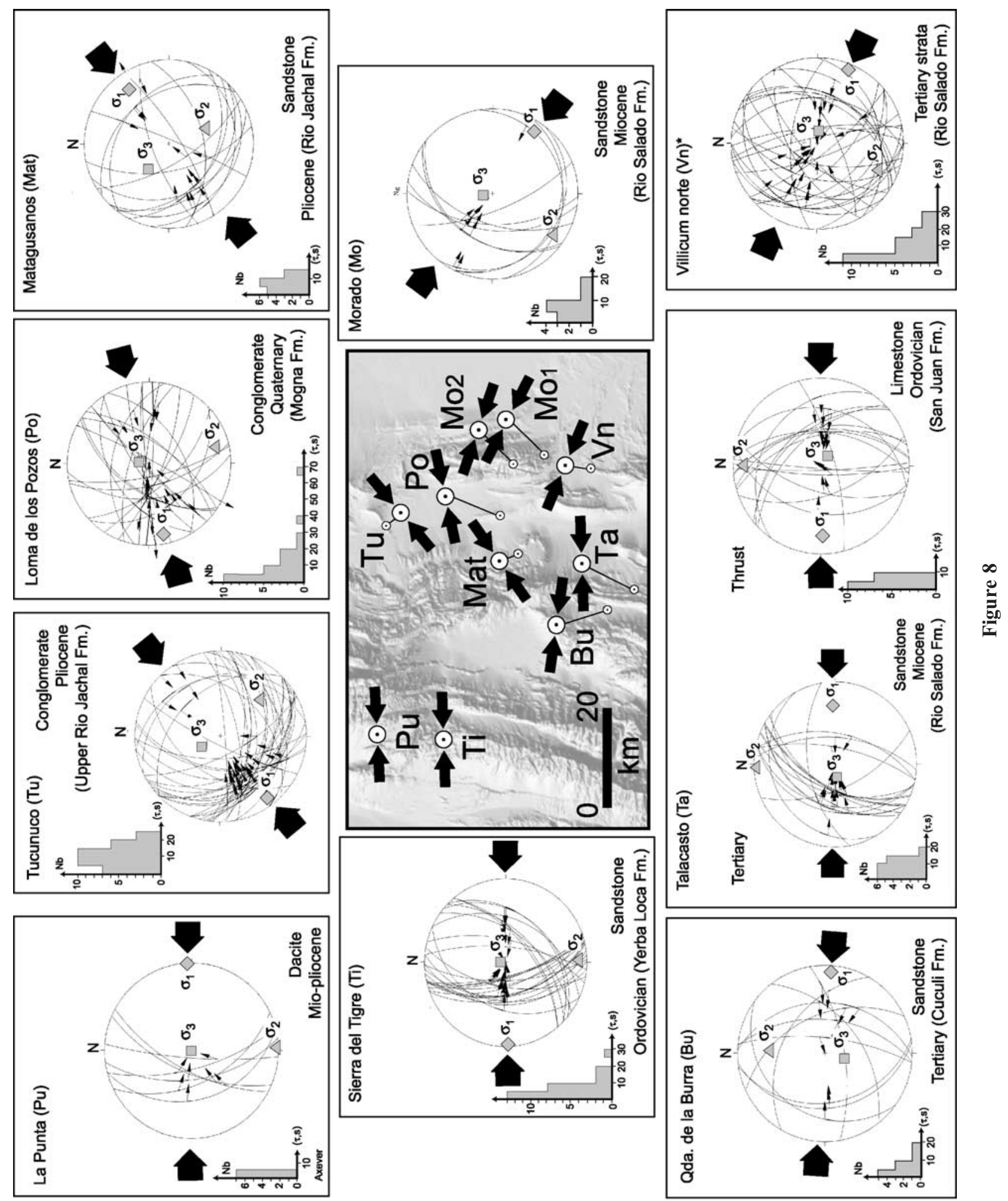


might be related to the early NW trending compressional stress regime. In such case, one possibility is to consider that local conditions such as the trend of the structures controlled the orientation of the $\sigma_{1}$ axes. After a quiescence period, dated at 5-3 Ma [Jordan et al., 1993], the deformation resumed with the creation of the Niquivil plate thanks to a high-angle breakthrough reverse fault [Zapata and Allmendinger, 1996], the San Roque plate being then passively transported on the back of the Niquivil thrust sheet [Jordan et al., 1993]. The second compressional stress regime might be related to this late deformation stage, for which $\sigma_{1}$ axes are roughly parallel to the direction of plate convergence (Figure 7).

\subsubsection{Stress Tensor Results for the Central and Eastern AP (Matagusanos Basin)}

[29] Within the Matagusanos basin, individual sites of fault slip measurements are located within the Río Jáchal formation near Tucunuco (Tu, Figure 7) and within de Matagusanos anticline (Ma, Figure 7), as well as within the Plio-Quaternary conglomerates from the Mogna formation at Loma de los Pozos (Po, Figures 7 and 8). At Tucunuco, fault striæ were collected within conglomerates that constitutes the upper part of the Río Jáchal formation $(<2.6 \mathrm{Ma})$. Inversion of those data yields a constrained stress tensor with $\mathrm{N} 50^{\circ} \mathrm{E}$ trending $\sigma_{1}$ axis. The Matagusanos structure is an anticline from the central AP that developed thanks to in sequence, foreland-directed propagation of reverse and thrust faults [Zapata and Allmendinger, 1996]. Fault slip data have been collected within the sandstones and upper conglomerates from the Río Jáchal formation. The stress tensor computed from those data is relatively well constrained and characterized by a $\mathrm{N} 55^{\circ} \mathrm{E}$ trending $\sigma_{1}$ axis. Both Tucunuco and Matagusanos sites show NE trending $\sigma_{1}$ axes, which are most probably reoriented respect to the regional trend depicted farther north along the Huaco section. Indeed, Tucunuco site is located close to the leftlateral ramp (Francia Fault) that marks the northern boundary of the Matagusanos basin [Zapata and Allmendinger, 1996]. Inversion of fault slip data collected at Matagusanos site yields a $\sigma_{1}$ axis roughly orthogonal to the NNW-SSE trend of the Matagusanos anticline, suggesting a local reorientation of $\sigma_{1}$ axis. At Loma de los Pozos, conglomerates from the Quaternary Mogna formation [Milana, 1990] are mainly composed of quartzite clasts showing well-expressed slickenslides and penetrative stylolithes. Inversion of the measured fault slip vectors yields a reverse-faulting stress tensor with $\mathrm{N} 78^{\circ} \mathrm{E}$ trending $\sigma_{1}$ axis, similar to the stress states determined farther north for the central AP.

[30] At the western edge of the Matagusanos basin, the easternmost central AP is marked by a series of Permian and Carboniferous units that cuts the Matagusanos anticline
[Zapata and Allmendinger, 1996]. Farther south, the Matagusanos basin is also affected by the Talacasto out-ofsequence thrust. At Baños de Talacasto (Ta, Figures 7 and 8), where hydrothermal waters spring out from the thrust front, strata from the Mio-Pliocene, Río Paloma Formation (6.73.7 Ma [Milana, 1990]) are overthrusted by the west dipping San Juan Limestone. Fault slip data collected in both Ordovician and Neogene strata are in agreement with reverse faulting related to a $\mathrm{N} 90^{\circ} \mathrm{E}$ trending $\sigma_{1}$ axis. Moreover, fault slip data have also been measured in Upper Tertiary strata from the Cuculi formation [Milana, 1990] deposited on the back limb of the Talacasto thrust sheet (Bu, Figures 7 and 8), where evidence of deformation propagating up to the basis of the Quaternary alluvial deposits can be observed. Inversion of those data also provides a reverse-faulting stress state with a $\mathrm{N} 95^{\circ} \mathrm{E}$ trending $\sigma_{1}$ axis (Bu, Figures 7 and 8). All together, those observations strongly suggest that the Talacasto thrust sheet emplaced following an east trending compressional stress regime that may have been active up to the Quaternary. Since the Talacasto sheet is located at the same latitudes than the Sierra del Tigre, and parallel to the ETF right-lateral fault, those results are in close agreement with the idea that within this part of the AP, deformation might be partitioned at a crustal scale between strike-slip motion on the ETF and reverse dip-slip motion accommodated by the AP-SP thrusts.

\subsubsection{Stress Tensor Results for the Western and Central AP (Río San Juan Section)}

[31] Along the Río San Juan, mostly east trending imbrications are combined with folding and involve a sedimentary pile from Cambrian to Plio-Quaternary. Along this section, extensively studied by von Gosen [1992], four individual sites of fault slip measurements are available. Generally, Andean-related fault slip data comprise wellexpressed slickenslides, bedding slip calcite recrystallizations, as well as centimetric to decimetric grooves. Along the Río San Juan section, reverse-faulting stress tensors derived from inversion of fault slip data are consistent with east trending $\sigma_{1}$ axes. Fault slip data collected within the Carboniferous strata from the Dehesa Formation (SJ1, Figures 7 and 9) are not sufficiently distributed in terms of azimuth coverage. Inversion for this site is constrained using the additional assumption that $\sigma_{3}$ stress axis is purely vertical [e.g., Bellier and Zoback, 1995], yielding a $\mathrm{N} 81^{\circ} \mathrm{E}$ trending $\sigma_{1}$ axis. Inversion computed from fault slip data collected within the Devonian Talacasto Limestone (SJ2, Figures 7 and 9) yields a stress regime associated with the Rio Sasito thrust [e.g., von Gosen, 1992], whereas fault slip measurements from the Devonian Punta Negra Limestone provide insight for the stress regime associated with the Rio Saso thrust [e.g., von Gosen, 1992]. Inversion of the fault slip data for both sites yield deviatoric stress tensors with

Figure 8. Lower hemisphere stereoplots (Wulf) of reverse faulting. Individual fault planes and measured slip vectors at each site are plotted; arrows on fault planes point in directions of horizontal azimuth of the slip vectors. Stress axes obtained by inversions are shown by diamonds $\left(\sigma_{1}\right)$, triangles $\left(\sigma_{2}\right)$, and squares $\left(\sigma_{3}\right)$. Histograms show distribution of deviation angles between measured $s$ and predicted $\tau$ slip vector on each fault plane. Large arrows outside stereoplots give azimuth of maximum horizontal stress $\left(\sigma_{1}\right)$. The term "axever" indicates where inversion is constrained with the additional assumption that $\sigma_{1}$ axis is vertical. Asterisks indicate fault kinematic sites published by Siame et al. [2002]. 

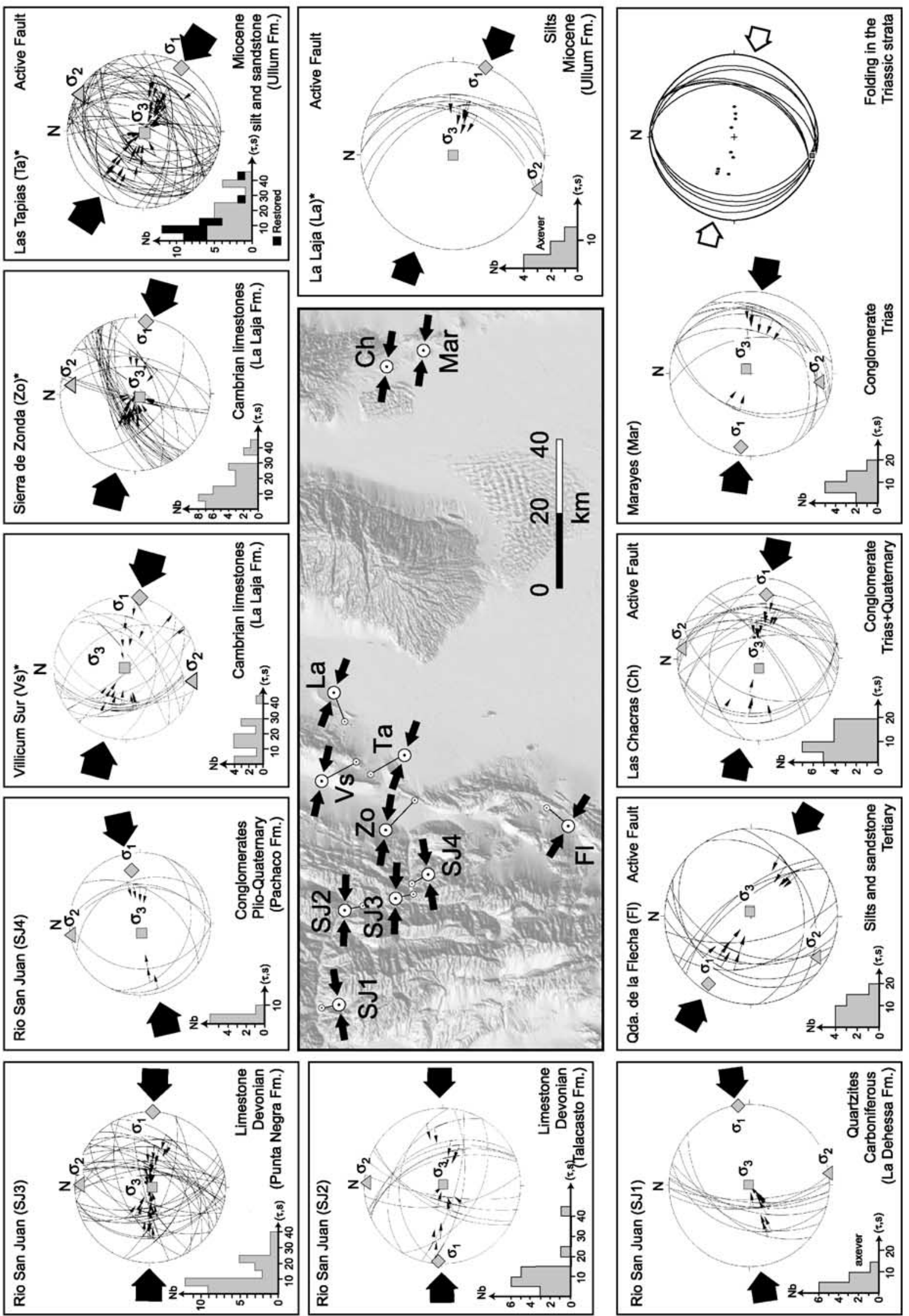
$\mathrm{N} 90^{\circ} \mathrm{E}$ trending $\sigma_{1}$ axes. The last measured site along the Río San Juan section is located in the western AP, west of the Tontal range, where Plio-Quaternary conglomerates with striated pebble faces allow calculating a recent stress state with $\mathrm{N} 80^{\circ} \mathrm{E}$ trending $\sigma_{1}$ axis (SJ4, Figures 7 and 9).

3.2.5. Stress Tensor Results for the Eastern AP (South of $31^{\circ} \mathrm{S}$ )

[32] Throughout a previous study focused on the eastern AP, Siame et al. [2002] showed that the reverse-faulting stress regime acting during the growth of the eastern AP is spatially homogeneous and temporally stable. The spatial homogeneity is evidenced by stress regimes computed from fault slip data measured along strike, whereas temporal stability is evidenced by chronologies relationships with prefolding fault slip data consistent with fault slips related with recent postfolding stress state [Siame et al., 2002]. Indeed, the stress regimes are based on fault slip data measured along the Las Tapias Fault scarp that is along one of the most active strand of the eastern AP, and consequently, the computed stress regime is representative for the Plio-Quaternary faulting. Fault slip data analysis along the eastern AP thrust showed that the Plio-Quaternary development of the eastern AP is dominated during initiation of folding, and westward thrusting with a mean continuous $\mathrm{N} 110 \pm 10^{\circ} \mathrm{E}$ trending $\sigma_{1}$ axis [Siame et al., 2002] (Figures 6, 8, and 9 and Table 3). Taking into account the $\mathrm{N} 20^{\circ} \mathrm{E}$ trending of eastern AP, it appears that the $\sigma_{1}$ axes are rotated clockwise respect to the convergence between Nazca and South American plates, nearly perpendicular to the strike of the eastern AP structures, in good agreement with the inversions and moment tensor sums computed from local and teleseismic focal mechanism data sets (Figure 7). Farther south, at Quebrada La Flecha within the Pedernal basin (Fl, Figures 7 and 9), fault slip data associated with reverse faulting affecting both Tertiary and Quaternary deposits, are also consistent with a $\mathrm{N} 120^{\circ} \mathrm{E}$ trending $\sigma_{1}$ axis. This reinforced the idea that south of $31^{\circ} \mathrm{S}$, the regional compressional stress regime is dominated by $\mathrm{N} 110 \pm 10^{\circ} \mathrm{E}$ trending $\sigma_{1}$ axis perpendicular to the trend of the Sierra Pie de Palo, and parallel to the trend of the NPF (Figure 7).

\subsubsection{Stress Tensor Results for the Western Sierras Pampeanas}

[33] To better constrain the stress regime acting in the SP domain, fault slip data have been collected within the Triassic and Plio-Quaternary strata that crop out at the southern (La Huerta range) and northern (Valle Fértil range) ends of the NW trending Pampean range located east of the Sierra Pie de Palo. The southern end of La Huerta range is mainly constituted by Triassic strata folded following north trending axial planes. Fault slip data collected at Marayes (Ma, Figure 7) within indurated, Triassic conglomeratic red beds, allow calculating stress states that unveiled an earlier normal faulting regime characterized by a NE trending extension, probably related to the Triassic rifting of the Cuyo basin. Reverse striae and calcite recrystallizations are related with a more recent compression phase related with a $\mathrm{N} 100^{\circ} \mathrm{E}$ trending $\sigma_{1}$ axis, which agrees with the trend of the fold axes (Figure 9). The Las Chacras Fault (Ch, Figure 6), is a reverse active fault [Costa et al., 2000, and references herein] which surface trace clearly affect the Plio-Quaternary alluvial deposits that skirt the western piedmont of $\mathrm{La}$ Huerta range [Siame, 1998]. Fault slip data measurements have been realized within the fault zone, where PlioQuaternary conglomerates are overthrusted by Triassic strata (Figure 9). When compared, the Marayes and Las Chacras sites clearly indicate that during a recent period, the southern end of La Huerta range has experienced a compressional state of stress with a $\mathrm{N} 100^{\circ} \mathrm{E}$ trending $\sigma_{1}$ axis, which is consistent with the stress regime determined using the teleseismic and local focal mechanism solutions associated with the Sierra Pie de Palo, $40 \mathrm{~km}$ farther east.

[34] Farther north, the Valle Fértil range continuity is marked by the Sierra Morada (Figure 7), which corresponds to a broad anticline termination bordered to the west by the Valle Fertil Fault (VFF), a high-angle, reverse fault [Zapata and Allmendinger, 1996]. The western flank slope is much steeper than the eastern one where the Triassic strata crop out in Valle de la Luna (Ischigualasto area). This continental sequence, related to the development of an asymmetric, Triassic, half graben, is now gently shortened and forms a broad anticline, associated with the inversion $(\sim 1.2-1.4 \mathrm{Ma})$ of the VFF [Zapata and Allmendinger, 1996]. Evidence of compressional deformation can be inferred at a regional scale. Indeed, the eastern flank of Sierra Morada is affected by conjugated strike-slip faults that can be observed at different space scale, from several meters to several kilometers (Figure 10). The first set comprises a series of rightlateral, $\mathrm{N} 70^{\circ} \mathrm{E}$ trending faults, whereas the second one is composed of left-lateral, $\mathrm{N} 105^{\circ} \mathrm{E}$ trending structures (Figure 10). Both sets of faults have conspicuous surface traces disrupting the Triassic strata, and correspond to a stress regime where $\sigma_{1}$ axis is striking roughly $\mathrm{N} 80^{\circ} \mathrm{E}$. Even though the Triassic strata are mainly composed of unconsolidated silts and sands, and constitute very weak material respect to the preservation of fault striæ, one can also observe similar conjugated strike-slip minor fault planes (Figure 10). Within the Triassic strata that arm the core of Ischigualasto area, the deformation is mostly characterized by north striking fold axes as well as $\mathrm{N} 70^{\circ} \mathrm{E}$ trending and

Figure 9. Lower hemisphere stereoplots (Wulf) of reverse faulting. Individual fault planes and measured slip vectors at each site are plotted; arrows on fault planes point in directions of horizontal azimuth of the slip vectors. Stress axes obtained by inversions are shown by diamonds $\left(\sigma_{1}\right)$, triangles $\left(\sigma_{2}\right)$, and squares $\left(\sigma_{3}\right)$. Histograms show distribution of deviation angles between measured $s$ and predicted $\tau$ slip vector on each fault plane. Large black arrows outside stereoplots give azimuth of maximum horizontal stress $\left(\sigma_{1}\right)$. The term "axever" indicates where inversion is constrained with the additional assumption that $\sigma_{1}$ axis is vertical. For the Las Tapias site, early fault planes, restored taking into account the stratification $\left(\mathrm{N} 32^{\circ} \mathrm{E} 90^{\circ}\right)$, have been added for inversion and show that the computed stress regime is relatively stable during folding [Siame et al., 2002]. Asterisks indicate fault kinematic sites published by Siame et al. [2002]. 

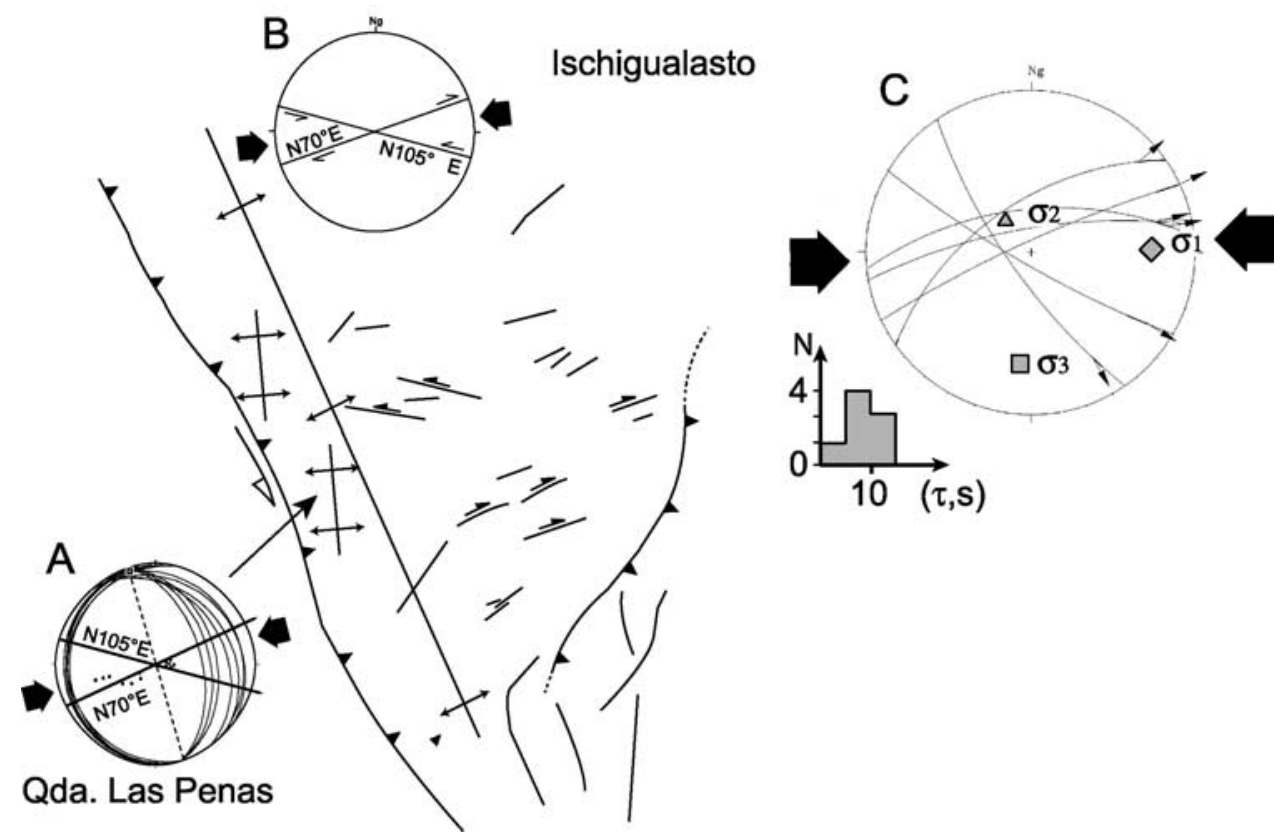

Figure 10. Simplified structural map for the northern termination of the Sierra Valle Fertil. (a) N-S striking folds axes and conjugated shear joints compatible with a $\mathrm{N} 70^{\circ} \mathrm{E}$ trending compression. (b) Conjugated strike-slip faults, observed at different space scale, as well as N-S trending folds suggest a regional compressional direction striking $\mathrm{N} 70-80^{\circ} \mathrm{E}$. (c) Lower hemisphere stereoplots (Wulf) showing inversion results for fault slip vectors measured in the unconsolidated Triassic silts. Histograms show distribution of deviation angles between the measured $s$ and the predicted $\tau$ slip vector on each plane.

$\mathrm{N} 105^{\circ} \mathrm{E}$ trending conjugated shear joints compatible with a $\mathrm{N} 80^{\circ} \mathrm{E}$ trending compression (Figure 10). At a regional scale, the fact that only gentle deformation can be observed is in agreement with a Plio-Quaternary reactivation of the main structure. All together the observations suggest that the northern end of Valle Fértil range has experienced a recent compressional regime characterized by a N70-80 $\mathrm{E}$ trending $\sigma_{1}$ axis, consistent with the stress regime computed from fault slip vectors measured within the San Roque and Niquivil thrust sheets, near Jáchal.

\subsection{Quaternary Versus Long-Term Rates of Deformation}

[35] During the past decade, several studies provided relatively accurate estimates of the Quaternary deformation rates along several active faults in the sub-Andean Foreland of San Juan. One of the first worldwide applications of the cosmic ray exposure (CRE) method [e.g., Gosse and Phillips, 2001] was dedicated to the study of the El Tigre Fault (ETF). Along the southern segment of this active fault, alluvial fans skirting the western piedmont of the AP are incised by a drainage network of stream channels, gullies, and ridges. Most of these geomorphic markers provide evidence for right-lateral displacements, with a maximum offset of $260 \pm 20 \mathrm{~m}$ cumulated during Late Quaternary [Siame et al., 1997a, 1997b]. Thanks to CRE dating of the alluvial fan surfaces incised by the deformed drainage network, Siame et al. [1997a] estimated that the channel incision took place between $380 \pm 78 \mathrm{ka}$ and $100 \pm 21 \mathrm{ka}$, yielding an horizontal slip rate for the ETF of about $1 \mathrm{~mm} \mathrm{yr}^{-1}$

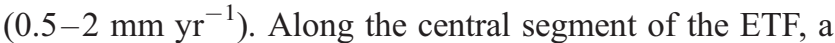
beheaded series of alluvial fans is uplifted by pressure ridges formed within local fault strands. CRE dating of these alluvial surfaces yielded a local vertical slip rate on the order of $0.3 \mathrm{~mm} \mathrm{yr}^{-1}$ [Siame et al., 1997b]. More recently, another geomorphic study provided insights for the Quaternary rate of deformation associated with the eastern AP, and more precisely to the Villicúm-Pedernal thrust fault [Siame et al., 2002]. In this study, Siame et al. focused on one of the most recent segments of this regional thrust (the Las Tapias fault) where a west facing, $\sim 10 \mathrm{~m}$ high discontinuous and degraded scarp affect Quaternary alluvial deposits. CRE dating of the deposit surfaces, combined with a topographic survey of the scarp yielded an estimate of a minimum shortening rate of $\sim 0.8 \pm 0.5 \mathrm{~mm} \mathrm{yr}^{-1}$ over the last $\sim 20 \mathrm{kyr}$. This shortening rate is consistent with the $\sim 1 \mathrm{~mm} \mathrm{yr}^{-1}$ shortening rate determined farther north over the past 3 Myr by Zapata and Allmendinger [1996] across eastern AP and Bermejo basin individual structures.

[36] Previous study [e.g., Allmendinger et al., 1990; Cristallini and Ramos, 2000], have shown that Andean orogeny may have resulted in more than $90 \mathrm{~km}$ of shortening accommodated by the Argentine Precordillera, yielding a mean shortening rate of $5 \mathrm{~mm} \mathrm{yr}^{-1}$ if integrated over the last 20 Myr. Age of shortening in the east verging AP is relatively well known at about $30^{\circ} \mathrm{S}$ [e.g., Jordan et al., 1993; Zapata and Allmendinger, 1996], whereas it is less constrained at $\sim 31^{\circ} \mathrm{S}$. Near $30^{\circ} \mathrm{S}$, age and amount of shortening have been estimated mostly through magneto- 
stratigraphy and growth strata: the western AP experienced an early phase of shortening roughly $20 \mathrm{Ma}$ (rates $<5 \mathrm{~mm} \mathrm{yr}^{-1}$ ) followed by a period of quiescence [Jordan et al., 1993]. Thrusting in the western and central AP then resumed at roughly 15 Ma with a period of rapid rates $\left(15-20 \mathrm{~mm} \mathrm{yr}^{-1}\right)$ spanning at about 10-12 Ma, followed by declining rates [Jordan et al., 1993; Zapata and Allmendinger, 1996], even though some of the easternmost thrusts may have been active throughout the Quaternary [Zapata and Allmendinger, 1996; Siame, 1998]. Those previous studies have shown that the deformation front of the AP has experienced a total shortening of $\sim 40 \mathrm{~km}$ during the last $5 \mathrm{Myr}$, implying a mean geological shortening rate of $\sim 8 \mathrm{~mm} \mathrm{yr}^{-1}$. Regarding the eastern AP and the Bermejo Valley, they accommodated $\sim 17 \mathrm{~km}$ of shortening during the last 2.7 Myr [Zapata, 1998], yielding a mean deformation rate of about $6.5 \mathrm{~mm} \mathrm{yr}^{-1}$. The amount of shortening associated with the Sierra Pie de Palo is on the order of $15 \mathrm{~km}$ and may have started between 5 and $3 \mathrm{Ma}$ [Jordan et al., 2001], yielding a mean shortening rate of $3-5 \mathrm{~mm} \mathrm{yr}^{-1}$.

\section{Discussion and Conclusions}

[37] Flat subduction process has long been suggested to be responsible for the high level of crustal seismicity associated with the large-scale, ongoing Pampean thickskinned basement uplifts [e.g., Jordan et al., 1983; Gutscher et al., 2000; Ramos et al., 2002]. Inversions and moment tensor sums of focal mechanism solutions along the Chilean margin $\left(22^{\circ} \mathrm{S}-36^{\circ} \mathrm{S}\right)$ and within the foreland of San Juan $\left(29^{\circ} \mathrm{S}-33^{\circ} \mathrm{S}\right)$ raised the following points: (1) the slight convergence obliquity at the plate boundary is accommodated by the subduction zone itself, precluding any deformation partitioning at lithospheric scale, (2) clockwise rotation of $\sigma_{1}$ and $P$ axes within the Andean foreland of western Argentina suggest that deformation partitioning may occur in the upper plate at crustal scale, and (3) comparing seismic rates of shallow deformations determined from moderate to large earthquakes localized between $22^{\circ} \mathrm{S}$ and $36^{\circ} \mathrm{S}$ shows that the amount of shortening is about the same $\left(2-4 \mathrm{~cm} \mathrm{yr}^{-1}\right)$ between the forearcs of the $30^{\circ}$ dipping slab segments and the back arc of the flat segment. Interestingly, the trench segment corresponding to flat subduction is characterized by a much lower seismic moment release during the last 30 years. Whether the strain partitioning suggested by both seismic data (coseismic movement) and GPS-derived velocity field (elastic strain field) is recorded at a much longer timescale than the last 30 years has been investigated through the analysis of the Neogene to Quaternary tectonic regimes.

[38] Stress regimes controlling the Neogene to Quaternary structural development of the AP and westernmost SP are constrained by inversion of fault slip vector data (Figure 7). In the Argentine Precordillera, Paleozoic to Quaternary strata are involved in the deformation, which is related to the Andean $(<20 \mathrm{Myr})$ structuration of the region. Since the AP developed eastwardly during the last $20 \mathrm{Myr}$, the fault slip sites determined for the western AP are most probably older than those calculated for the central AP, eastern AP and
SP. In the western and central AP, where the thrust mainly developed between 20 and $5 \mathrm{Ma}$ [Jordan et al., 2001], the stress regime is dominated by $\sigma_{1}$ axes striking parallel to that determined for the Chilean trench. In the westernmost SP and eastern AP, where the thrust initiated between 5 and $2.5 \mathrm{Myr}$, the stress regimes are dominated by $\mathrm{N} 110^{\circ} \mathrm{E}$ trending $\sigma_{1}$ axes south of $31^{\circ} \mathrm{S}$, whereas it is striking parallel to that determined for the Chilean trench north of $31^{\circ} \mathrm{S}$ (Figure 7). Since the computed stress regimes are associated with the development of the westernmost SP and eastern AP reverse structures [Zapata and Allmendinger, 1996; Ramos et al., 2002], the observed clockwise reorientation may have started 5-2.5 Myr ago, that is to say since the Sierra Pie de Palo anticline is actively growing. Taking into account the mechanical assumptions underlying the fault slip data inversion methodology (see Appendix A), and as illustrated by our results in the subduction zone, deviatoric stress and strain tensor axes can be considered to be parallel. This allows comparing the stress regime pattern to the GPSderived velocity field proposed by Brooks et al. [2003]. The stress regime pattern derived from fault slip vector data in the eastern AP and westernmost SP is in relative agreement. In the northern part of the San Juan foreland both $\sigma_{1}$ axes and GPS-derived velocity vectors strike in a direction parallel to that of the plate convergence (Figure 7). Farther south, the comparison is not so conspicuous with GPSderived velocity vectors striking E-W (Figure 7). Nevertheless, GPS-derived velocity vectors seem to be also clockwise rotated, suggesting that the clockwise rotation of $\sigma_{1}$ axes evidenced from both focal mechanism (present-day) and fault slip vector (long-term) data sets may also be seen in the GPS-derived velocity field despite the upper plate elastic loading (Figure 7).

[39] All together those remarks and results lead us to consider the Andean back arc of western Argentina as an obliquely converging foreland where Plio-Quaternary deformations are partitioned between strike-slip and thrust motions that are localized on the east verging thin-skinned Argentine Precordillera and the west verging thick-skinned Pampean Ranges, respectively. In this partitioning model the ETF, eastern AP and western SP faults play important roles. The ETF geometry and segmentation is tightly associated with the geometry of the AP ranges. Indeed, slight variations of strike in the AP range appear to parallel the ETF geometry and discontinuities [Siame et al., 1997b]. For example, the southern termination of the ETF coincides with the AP ranges bending from $\mathrm{N} 160^{\circ} \mathrm{E}$ to $\mathrm{N} 10^{\circ} \mathrm{E}$ close to Río San Juan. Along its northern segment, the ETF steps westward, splaying as a horse-tail termination, coinciding to another orientation change of the Precordilleran ranges (Figure 7). Among others, these observations lead Siame et al. [1997b] to propose that the ETF may correspond to a crustal-scale strike-slip fault, closely related to the Precordilleran thrust-and-fold belt. In this Plio-Quaternary transpressive system, the ETF should accommodate the dextral strike-slip component while the eastern AP-Pampean thrusts should accommodate $\mathrm{N} 110^{\circ} \mathrm{E}$ trending shortening (Figure 7). Indeed, if one assumes that the convergence obliquity is accommodated by the ETF, Quaternary slip rates estimated 
thanks to CRE dating $\left(\sim 1 \mathrm{~mm} \mathrm{yr}^{-1}\right)$ imply that $3-8 \mathrm{~mm} \mathrm{yr}^{-1}$ of shortening have to be accommodated throughout the eastern AP-Pampean system in a $\mathrm{N} 110^{\circ} \mathrm{E}$ trending direction (Figure 7). Interestingly, this direction corresponds to the orientation of the $\sigma_{1}$ axes computed from both focal mechanism (present-day) and fault kinematic (long-term) data sets within the eastern AP and westernmost SP. This direction also coincides with the trend of the North Pie de Palo Fault (NPF) that marks the northern limit of the growing Sierra Pie de Palo (Figure 5) and corresponds to a regional structure that plays a major role within the earthquake distribution pattern (Figure 3).

[40] In our partitioning model, the estimated range of Quaternary shortening rates $\left(3-8 \mathrm{~mm} \mathrm{yr}^{-1}\right)$ is in close agreement with the geological rates estimated from crustal balancing studies [e.g., Allmendinger et al., 1990; Cristallini and Ramos, 2000]. Since this range of shortening rates has to be distributed over several active thrusts, it is also consistent with a $\sim 1 \mathrm{~mm} \mathrm{yr}^{-1}$ minimum shortening rate determined for the Las Tapias Fault of the eastern AP south of $31^{\circ} \mathrm{S}$ over the Holocene period [Siame et al., 2002]. Even if one argued as to the degree to which the GPS data are accurate, these data suggest that south of $31^{\circ} \mathrm{S}, 7-9 \mathrm{~mm} \mathrm{yr}^{-1}$ of east trending shortening have to be accommodated between the Calingasta Valley and Sierra Pie de Palo, with about $4 \mathrm{~mm} \mathrm{yr}^{-1}$ between eastern AP and Sierra Pie de Palo [Brooks et al., 2003]. Those GPS-derived shortening estimates are thus slightly higher than the long-term geological and Quaternary rates. Moreover, north of $31^{\circ} \mathrm{S}$, GPS data suggest that only 2$3 \mathrm{~mm} \mathrm{yr}^{-1}$ are accommodated between the western AP and the Sierra de Valle Fértil, with less than $1 \mathrm{~mm} \mathrm{yr}^{-1}$ within the Bermejo valley. GPS data thus seem to confirm that most of the present-day tectonic activity is concentrated around the Sierra Pie de Palo, south of $31^{\circ} \mathrm{S}$, as suggested by the regional earthquake distribution (Figure 3). In this context, the shortening rate estimated from seismic moment tensor sum appears to be one order of magnitude greater $\left(3-4 \mathrm{~cm} \mathrm{yr}^{-1}\right)$ than those estimated above from the GPS-derived velocity field. This high rate of coseismic shortening strongly suggests that the November 1977 earthquake may have released the elastic deformation accumulated in this region, the high discrepancy with GPS-derived and geological shortening rates being much probably due to the too short-spanned time window.

\section{Appendix A: Methodologies}

\section{A1. Present-Day Stress Regime From Inversion of Focal Mechanism Solutions}

[41] The numerical approach proposed by CareyGailhardis and Mercier [1987] allows studying, in terms of stress, the kinematic characteristics of seismogenic faults provided by focal mechanism data sets. This approach assumes a mean state of stress in the source region and is based on the simple mechanical model used for fault population analyses (see hereafter), which supposes slip in the direction of the resolved shear stress acting on the fault plane [e.g., Bott, 1959]. Data homogeneity and space where the principal stress axes have to be searched can be tested defining compressional and tensional zones resulting from the superimposition of the compressional and tensional quadrants limited by the nodal planes (e.g., right-dihedra method). Then, for each principal stress reference whose location is constrained by the confined zones, the $R$ ratio $\left(R=\left[\left(\sigma_{2}-\sigma_{1}\right) /\left(\sigma_{3}-\sigma_{1}\right)\right]\right.$, see section A1.3) is computed which fits the slip vector on each nodal plane, allowing one to select a set of preferred seismic fault planes from the auxiliary plane data set. Finally, from this set of preferred seismic fault plane, a state of stress can be computed using the nonlinear simplex method usually applied to fault population analyses [e.g., Carey and Brunier, 1974; Carey, 1979].

\section{A2. Seismic Rate of Deformation From Seismic Moment Sums of Focal Mechanism Solutions}

[42] Following Aki [1966] and Hanks and Kanamori [1979], the seismic moment is defined as $M_{0}=\mu A u$, where $M_{0}$ is the scalar seismic moment, $\mu$ is the shear modulus $\left(\sim 6 \times 10^{11} \mathrm{dyn} \mathrm{cm}^{-2}\right.$ in interplate subduction settings; $\sim 3 \times 10^{11} \mathrm{dyn} \mathrm{cm}^{-2}$ in brittle crust environments), $\mathrm{A}$ is the surface area of the considered fault, and $u$ is the average coseismic displacement. The cumulative slip on a fault can be estimated by summing the seismic moments of earthquakes causing slip on a fault [e.g., Brune, 1968]. Brune's [1968] is well suited for summing seismic moments in subduction interplate settings, the cumulative slip on the subduction plane being calculated using:

$$
\bar{u}=\sum_{x=1}^{N} \bar{u}(x)=\frac{1}{\mu A} \sum_{x=1}^{N} M_{0}(x)
$$

and assuming that all the coseismic deformation is effectively released at the interface between the subducting and upper plates. Brune's [1968] formula can strictly be used if all the focal solutions within a given region only differ by the scalar value of their moment. One possible way to check for consistency of the studied focal solution data set is to use the coherence criterion (CC) defined by Frohlich and Apperson [1992] as the ratio of the moment scalar value of the sum and the sum of the individual scalar moments. The scalar moment of the sum can be calculated using [Silver and Jordan, 1982]

$$
M_{o}=\sqrt{\frac{\left(m_{T}^{2}+m_{B}^{2}+m_{P}^{2}\right)}{2}}
$$

In the intraplate domain, the seismic energy is generally not released on a single but on several fault planes with different orientation distributed within a specific volume. In such case, Kostrov's [1974] methodology is more suitable as it uses the seismic moment tensors to calculate the strain resulting from seismic slip of all the faults in the region. The seismic moment tensor for a single rupture event may be expressed as

$$
M_{i j}=\mu A\left(u_{i} v_{j}+u_{j} v_{i}\right)
$$

where $v_{i}$ are the direction cosines of the vectors normal to the nodal plane and $u_{i}$ is the average slip in a vectorial form 
[Aki and Richards, 1980; Ben-Menahem and Singh, 1981]. The principal values of the moment tensor $-M_{0}, 0$, and $+M_{0}$, correspond to the $P, B$, and $T$ axes of the fault plane solution [Gilbert, 1970; Súarez et al., 1983]. Following Kostrov's [1974] method, the mean rate of irrotational strain $\left(\dot{\varepsilon}_{i j}\right)$ in a volume $V$ over a period of time $t$ due to slip on $N$ different faults located within that volume is given by

$$
\dot{\varepsilon}_{i j}=\frac{1}{2 \mu V t} \sum_{n=1}^{N} M_{i j}^{n}
$$

The principal directions of the strain rate are calculated by diagonalizing $\dot{\varepsilon}_{i j}$. Crustal shortening rate is thus calculated by multiplying the horizontal component of the maximum compressional strain rate $\left(\dot{\varepsilon}_{i j} \mathrm{Hmax}_{\mathrm{max}}\right)$ times the width of the deformed volume in the direction of $\dot{\varepsilon}_{i j}$ Hmax [e.g., Súarez et al., 1983]. In equation (A4), the member $\sum_{n=1}^{N} M_{i j}^{n}$ represents the seismic moment sum. The methodology used to calculate this seismic moment sum is fully described by Jost and Herrmann [1989].

\section{A3. Long-Term Stress Regime From Inversion of Fault Plane Populations}

[43] The kinematics of a fault population can be defined using the striations observed on the fault planes. Constraints on the stress regime during mountain building can be provided by inversions of fault slip vectors on minor or major fault planes. Assuming that the slip vectors represented by the striations occur in the direction of the maximum resolved shear stress on each fault plane [see Bott, 1959] and minimizing the angular deviation between a predicted slip vector $(\tau)$ and the striation (s) measured in the field, the observation of numerous fault planes can be inverted to compute a mean best fitting deviatoric stress tensor [see Carey and Brunier, 1974; Carey, 1979; Angelier, 1990; Mercier et al., 1991]. This method supposes that rigid block displacements are independent. The inversion results include the orientation (azimuth and plunge) of the three principal stress axes of a mean deviatoric stress tensor as well as a stress ratio $\left(R=\left[\left(\sigma_{2}-\sigma_{1}\right) /\left(\sigma_{3}-\sigma_{1}\right)\right]\right)$, a linear quantity describing relative stress magnitude. Principal stress axes correspond to the compressional $\left(\sigma_{1}\right)$, intermediate $\left(\sigma_{2}\right)$ and extensional $\left(\sigma_{3}\right)$ deviatoric stress axes, respectively. The stress ratio $\mathrm{R}$ describes the relative stress magnitudes of the calculated mean deviatoric stress tensor. Indeed, the stress ratio defines the shape of a stress ellipsoid. To compare $R$ values of distinct stress deviators in term of stress magnitude variation, it is necessary that the compared stress deviators are coaxial (i.e., have the same principal axis directions) for being represented on a Mohr's circle. Discussion of the stress ratio significance in inter- preting inversion results is presented by Bellier and Zoback [1995]. As defined, the $R$ value varies between two endmember uniaxial stress states, i.e., $R=0$ when $\sigma_{2}=\sigma_{1}$, and $R=1$ when $1 \sigma_{2}=\sigma_{3}$. In a strike-slip faulting stress regime (where vertical stress $\sigma_{v}=\sigma_{2}$, maximum horizontal stress $\sigma_{\text {Hmax }}=\sigma_{1}$, and minimum horizontal stress $\sigma_{\text {hmin }}=\sigma_{3}$ ), the $\mathrm{R}=0$ end-member corresponds to a stress state transitional to normal faulting (extensional regime), in which $\sigma_{\mathrm{Hmax}}=$ $\sigma_{v}$, whereas the $R=1$ end-member represents a stress state transitional to thrust faulting (compressional regime), in which $\sigma_{\text {hmin }}=\sigma_{v}$. For $R$ values close to 0 or to 1 , the near-transitional (i.e., near uniaxial when $0.85<R<1$ and $0<R<0.15)$ stress states require only minor fluctuation of stress magnitudes to go from one stress regime to other, i.e., from a strike-slip to an extensional regime, or from a strikeslip to a compressional regime. Thus such regimes are characterized by mixed modes of faulting: dip, oblique, and strike slip. Between the uniaxial stress states, the intermediate $\mathrm{R}=0.5$ ratio indicates a biaxial stress state characterized by an intermediate stress, $\sigma_{2}$, equal to zero (because $\left|\sigma_{1}\right|+\left|\sigma_{2}\right|+\left|\sigma_{3}\right|=0$ for a stress deviator). Between, these specific near uniaxial $(0.85<R<1$ and $0<R<0.15)$ and near biaxial $(0.45<R<0.55)$ stress states, stress tensors characterized common triaxial stress states. For triaxial deviators, $R$ values higher than 0.55 represent transpressional strike-slip regimes in which $\sigma_{2}$ is tensional, whereas $R$ values lower than 0.45 correspond to transtensional regimes, in which $\sigma_{2}$ is compressional.

[44] Taking into account the mechanical assumptions, the computed stress ellipsoid is "coaxial" with the strain ellipsoid. Results of stress inversions are generally considered reliable if $80 \%$ of angular deviations $(\mathrm{s}, \tau)$ are less than $20^{\circ}$ and if the computed solution is stable. Any inversion thus requires at least four independent fault sets to quantify the orientation of the principal axes and the stress ratio $R$. Ideal sets of data contain faults dipping in two directions with distinct strike directions, not just a continuum of strikes around a single mean direction [Bellier and Zoback, 1995]. Stress regime can thus be computed from poorly distributed fault sets with the additional assumption that one of the stress axes is purely vertical; consequently there are only two unknowns: the orientation of one of the horizontal stresses and the stress ratio.

[45] Acknowledgments. This study was realized within the cooperative agreement between ORSAYTERRE (UMR 8616, Université de Paris-Sud, Orsay, France) and the INPRES (Instituto Nacional de Prevencion Sismica, San Juan, Argentina). SPOT images used for the structural analysis were supported by the ISIS-CNES program. We would like to thanks M. Régnier for providing us with the focal solutions from Régnier et al. [1992] and M. Perez and G. Racciopi for helpful assistance in the field. Thanks to C. Costa, P. Victor, and D. Hindle for constructive remarks and reviews.

\section{References}

Aki, K. (1966), Generation and propagation of $\mathrm{G}$ waves from the Niigata earthquake of June 16, 1964; part 2, Estimation of earthquake moment, released energy, and stress-strain drop from $\mathrm{G}$ wave spectrum, Bull. Earthquake Res. Inst. Univ. Tokyo, 44, 73-88.
Aki, K., and P. G. Richards (1980), Quantitative Seismology: Theory and Method, pp. 559-935, W. H. Freeman, New York.

Allmendinger, R. W., D. Figueroa, D. Snyder, J. Beer, C. Mpodozis, and B. L. Isacks
(1990), Foreland shortening and crustal balancing in the Andes at $30^{\circ} \mathrm{S}$ latitude, Tectonics, 9, 789809 .

Angelier, J. (1990), Inversion of field data in fault tectonics to obtain the regional stress-part II: A new 
rapid direct inversion method by analytical means, Geophys. J. Int., 103, 363-376.

Baldis, B. A., M. S. Beresi, O. Bordonaro, and A. Vaca (1982), Síntesis evolutiva de la Precordillera de Argentina, paper presented at 5th Congreso Latinoamericano de Geología, Serv. Interam. de Serv. Geol., Buenos Aires, Argentina.

Bastias, H. (1985), Fallamiento Cuaternario en la region sismotectonica de precordillera, Ph.D. thesis, 160 pp., Fac. de Cien. Exactas, Fis. y Nat., Univ. Nac. de San Juan, San Juan, Argentina.

Beer, J. A., R. W. Allmendinger, D. A. Figueroa, and T. E. Jordan (1990), Seismic stratigraphy of a Neogene piggy-back basin, Argentina, $A A P G$ Bull., 74, 1183-1202.

Bellier, O., and M. L. Zoback (1995), Recent state of stress change in the Walker Lane zone, western Basin and Range province, United States, Tectonics, 14, 564-593.

Ben-Menahem, A., and S. J. Singh (1981), Seismic Waves and Sources, pp. 893-897, Springer, New York.

Bott, M. H. P. (1959), The mechanism of oblique slip faulting, Geol. Mag., 96, 109-117.

Brooks, B. A., M. Bevis, R. Smalley Jr., E. Kendrick, R. Manceda, E. Lauría, R. Maturana, and M. Araujo (2003), Crustal motion in the southern Andes $\left(26^{\circ}-36^{\circ} \mathrm{S}\right)$ : Do the Andes behave like a microplate?, Geochem. Geophys. Geosyst., 4(10), 1085, doi:10.1029/2003GC000505.

Brune, J. N. (1968), Seismic moment, seismicity and rate of slip along major fault zone, J. Geophys. Res., $73,777-784$.

Cahill, T., and B. Isacks (1992), Seismicity and shape of the subducted Nazca plate, J. Geophys. Res., 97, $17,503-17,529$.

Caminos, R., C. A. Cingolani, F. Hervé, and E. Linares (1982), Geochronology of the pre-Andean metamorphism and magmatism in the Andean Cordillera between latitude $30^{\circ}$ and $36^{\circ} \mathrm{S}$, Earth Sci. Rev., 3, $333-352$.

Carey, E. (1979), Recherche des directions principales de contraintes associées au jeu d'une population de failles, Rev. Geol. Dyn. Geogr. Phys., 21, 5766.

Carey, E., and B. Brunier (1974), Analyse théorique et numérique d'un modèle mécanique élémentaire appliqué à l'étude d'une population de failles, $C . R$ Acad. Sci., Ser. D, 279, 891-894.

Carey-Gailhardis, E., and J.-L. Mercier (1987), A numerical method for determining the state of stress using focal mechanism of earthquake populations: Application to Tibetan teleseisms and microseismicity of southern Peru, Earth Planet. Sci. Lett., 82, $165-179$.

Carignano, C., et al. (1999), Landscape antiquity of the central eastern Sierras Pampeanas (Argentina): Geomorphological evolution since Gondwanic times, Z. Geomorphol., 118, 245-268.

Costa, C., M. N. Machette, R. L. Dart, H. E. Bastias, J. D. Paredes, L. P. Perucca, G. E. Tello, and K. M. Haller (2000), Map and database of Quaternary faults and folds in Argentina, U.S. Geol. Surv. Open File Rep., 00-0108, 81 pp., 1 map.

Cristallini, E. O., and V. A. Ramos (2000), Thickskinned and thin-skinned thrusting in La Ramada fold and thrust belt: Crustal evolution of the High Andes of San Juan, Argentina $\left(32^{\circ} \mathrm{S}\right.$ L), Tectonophysics, 317, 205-235.

DeMets, C., et al. (1990), Current plate motions, Geophys. J. Int., 101, 425-478.

DeMets, C., D. F. Gordon, D. F. Argus, and S. Stein (1994), Effect of recent revisions of the geomagnetic reversal time scale on estimates of current plate motions, Geophys. Res. Lett., 21, 21912194.

Dziewonski, A. M., T.-A. Chou, and J. H. Woodhouse (1981), Determination of earthquake source parameters from waveform data for studies of global and regional seismicity, J. Geophys. Res., 86, $2825-$ 2852 .
Engdahl, E. R., and A. Villaseñor (2002), Global seismicity: 1900-1999, in International Handbook of Earthquake and Engineering Seismology, Int. Geophys. Ser., vol. 81A, edited by W. H. K. Lee et al., pp. 665-690, Elsevier, New York.

Engdahl, E. R., R. van der Hilst, and R. Buland (1998), Global teleseismic earthquake relocation with improve travel times and procedures for depth determination, Bull. Seismol. Soc. Am. $88,722-743$

Farr, T. G., and M. Kobrick (2000), Shuttle Radar Topography Mission produces a wealth of data, Eos Trans. $A G U, 81,583,585$.

Frohlich, C., and K. D. Apperson (1992), Earthquake focal mechanisms, moment tensors, and the consisency of seismic activity near plate boundary, $T e c$ tonics, 11, 279-296.

Gilbert, F. (1970), Excitation of the normal modes of the earth by earthquake sources, Geophys. J. $R$. Astron. Soc. London, 22, 223-226.

Gosse, J. C., and F. M. Phillips (2001), Terrestrial in situ cosmogenic nuclides: Theory and applications, Ouat. Sci. Rev., 20(14), 1475-1560.

Gutscher, M. A., W. Spakman, H. Bijwaard, and E. R. Engdahl (2000), Geodynamics of flat subduction: Seismicity and tomographic constraints from the Andean margin, Tectonics, 19, 814-833.

Hanks, T. C., and H. Kanamori (1979), A moment magnitude scale, J. Geophys. Res., 84, 2348 -2350.

Hastings, D. A., and P. K. Dunbar (1998), Development and assessment of the Global Land One-km base digital elevation model (GLOBE), ISPRS Arch. 32(4), pp. 218-221, Int. Soc. for Photogramm. and Remote Sens., Stuttgart, Germany.

Jackson, J., and D. McKenzie (1988), The relationship between plate motions and seismic momen tensors, and the rates of active deformation in the Mediterranean and Middle East, Geophys. J., 93, $45-73$

Jordan, T. E., and R. W. Allmendinger (1986), The Sierras Pampeanas of Argentina: A modern analogue of Rocky Mountain foreland deformation, Am. J. Sci., 286, 737-764.

Jordan, T. E., B. Isacks, V. A. Ramos, and R. W. Allmendinger (1983), Mountain building in the central Andes, Episodes, 3, 20-26.

Jordan, T. E., R. W. Allmendinger, J. F. Damanti, and R. Drake (1993), Chronology of motion in a complete thrust belt: the Precordillera, $30-31^{\circ} \mathrm{S}$, Andes Mountains, J. Geol., 101, 135-156.

Jordan, T. E., F. Schlunegger, and N. Cardozo (2001), Unsteady and spatially variable evolution of the Neogene Andean Bermejo foreland basin, Argentina, J. S. Am. Earth Sci., 14, 775-798.

Jost, M. L., and R. B. Herrmann (1989), A student's guide to and review of moment tensors, Seismol. Res. Lett., 60, 37-57.

Kadinsky-Cade, K., and R. Reilinger (1985), Surface deformation associated with the November 23 , 1977, Caucete, Argentina, earthquake sequence, J. Geophys. Res., 90, 12,661-12,700.

Kagan, Y. Y. (2003), Accuracy of modern global earthquake catalogs, Phys. Earth Planet. Inter., 135 $173-209$.

Kay, S. M., and J. M. Abbruzzi (1996), Magmatic evidence for Neogene lithospheric evolution of the Central Andean "flat-slab" between 30 and $32^{\circ} \mathrm{S}$ Tectonophysics, 259, 15-28.

Kendrick, E., M. Bevis, R. Smalley, O. Cifuentes, and F. Galban (1999), Current rates of convergenc across the Central Andes: estimates from continuous GPS observations, Geophys. Res. Lett., 26 , $541-544$.

Kendrick, E., M. Bevis, R. Smalley, B. J. Brooks, R. Barriga Vargas, E. Lauría, and L. P. Souto Fortes (2003), The Nazca-South America Euler vector and its rate of change, J. S. Am. Earth Sci., 16, 125-131.

Kostrov, V. V. (1974), Seismic moment and energy of earthquakes, and seismic flow of rock, Izv. Russ. Acad Sci. Phys. Solid Earth 1, 23-44.

Llambias, E. J., and R. Caminos (1987), El magmatismo neopaleozoico de Argentina, in The Carbonifer- ous System of Argentina, edited by S. Archangelsky, pp. 253-271, Acad. Nac. de Cien., Argentina, Cordóba

Mercier, J. L., E. Carey-Gailhardis, and M. Sébrier (1991), Paleostress determinations from fault kinematics: application to the neotectonics of the Hymalayan-Tibet and the central Andes, Philos. Trans. R. Soc. London, Ser. A, 337, $41-52$

Milana, J. P. (1990), Sedimentología y magnetoestratigrafía de formaciones Cenozoicas en el área de Mogna y su inserción en el marco tectonosedimentario de la Precordillera Oriental, Ph.D. thesis, Univ. Nac. de San Juan, San Juan, Argentina.

Molnar, P., and S. Ghose (2000), Seismic moments of major earthquakes and the rate of shortening across the Tien Shan, Geophys. Res. Lett., 27, $2377-2381$.

Ortíz, A., and J. J. Zambrano (1981), La provincia geológica Precordillera Oriental: San Luis, VIII Congr Geol. Arg., 3, 59-74.

Pacheco, J. F., L. R. Sykes, and C. H. Scholz (1990), Nature of seismic coupling along simple plate boundaries of the subduction type, J. Geophys. Res., 98, 14,133-14,169.

Pilger, R. H. (1981), Plate reconstructions, aseismic ridges, and low angle subduction beneath the Andes, Geol. Soc. Am. Bull., 92, $448-$ 456.

Ramos, V. A. (1999), Plate tectonic setting of the Andean Cordillera, Episodes, 22(3), 183190

Ramos, V. A., T. E. Jordan, R. W. Allmendinger, C. Mpodozis, S. M. Kay, J. M. Cortés, and M. Palma (1986), Paleozoic terranes of the central Argentine-Chilean Andes, Tectonics, 5, $855-880$

Ramos, V. A., E. O. Cristallini, and D. J. Pérez (2002), The Pampean flat-slab of the central Andes, J. S. Am. Earth Sci., 15, 59-78.

Régnier, M., J.-L. Chatelain, R. Smalley, J.-M. Chiu, B. L. Isacks, and M. Araujo (1992), Seismotectonics of Sierra Pie de Palo: A basement block uplift in the Andean Foreland of Argentina, Bull. Seismol. Soc. Am., 82, 2549-2571.

Rosen, P. A., S. Hensley, I. R. Joughin, F. K. Li, S. N. Madsen, E. Rodriguez, and R. M. Goldstein (2000), Synthetic aperture radar interferometry, Proc. IEEE, $88,333-382$.

Salfity, J., and S. A. Gorustovich (1984), Paleogeografía de la cuenca del Grupo Paganzo, Paleozoico superior, Rev. Asoc. Geol. Arg., 38, 437453

Siame, L. L. (1998), Cosmonucléide produit in-situ $\left({ }^{10} \mathrm{Be}\right)$ et quantification de la déformation active dans les Andes centrales, Ph.D. thesis, Univ. de Paris-Sud, Orsay, France.

Siame, L. L., D. L. Bourlès, M. Sébrier, O. Bellier, J.-C. Castano, M. Araujo, M. Perez, G. M. Raisbeck, and F. Yiou (1997a), Cosmogenic dating ranging from 20 to $700 \mathrm{ka}$ of a series of alluvial fan surfaces affected by the El Tigre Fault, Argentina, Geology, $25,975-978$.

Siame, L. L., M. Sébrier, O. Bellier, D. L. Bourlès, J.-C Castano, and M. Araujo (1997b), Geometry, segmentation and displacement rates of the El Tigre fault, San Juan Province (Argentina) from SPOT image analysis and ${ }^{10} \mathrm{Be}$ datings, Ann. Tectonicae, $1(2), 3-26$.

Siame, L. L., O. Bellier, M. Sébrier, D. L. Bourlès, P. Leturmy, M. Perez, and M. Araujo (2002), Seismic hazard reappraisal from combined structural geology, geomorphology and cosmic ray exposure dating analyses: The Eastern Precordillera thrust system (NW Argentina), Geophys. J. Int., 150, $241-260$

Silver, P. G., and T. H. Jordan (1982), Optimal estimation of scalar seismic moment, Geophys. J. R. Astron. Soc., 70, 755-782.

Smalley, R. J., J. Pujol, M. Régnier, J.-M. Chiu, J.-L. Chatelain, B. L. Isacks, M. Araujo, and 
N. Puebla (1993), Basement seismicity beneath the Andean Precordillera thin skinned thrust belt and implications for crustal and lithospheric behavior, Tectonics, 12, 63-76.

Smith, W. H. F., and D. T. Sandwell (1997), Global sea floor topography from satellite altimetry and ship depth soundings, Science, 277, 19561962.

Súarez, G., and D. Comte (1993), Comment on "Seismic coupling along the Chilean subduction zone" by B. W. Tichelaard and L. R. Ruff, J. Geophys. Res., 98, 15,825-15,828.

Súarez, G., P. Molnar, and B. C. Burchfiel (1983), Seismicity, fault plane solutions, depth of faulting and active tectonics of the Andes of Peru, Ecua- dor and southern Colombia, J. Geophys. Res., 88, $403-428$.

Tichelaar, B. W., and L. R. Ruff (1991) Seismic coupling along the Chilean subduction zone, J. Geophys. Res., 96, 11,99712,022

von Gosen, W. (1992), Structural evolution of the Argentine Precordillera: The Río San Juan section, J. Struct. Geol., 14, 643-667.

Zapata, T. R. (1998), Crustal structure of the Andean thrust front an $30^{\circ} \mathrm{S}$ latitude from shallow and deep seismic reflection profiles, Argentina, J.S. Am. Earth Sci, 11, 131-151.

Zapata, T. R., and R. W. Allmendinger (1996), Thrust-front zone of the Precordillera, Argentina:
A thick-skinned triangle zone, AAPG Bull., 80, $359-381$.

M. Araujo, Instituto Nacional de Prevención Sísmica, Roger Ballet, 5400, San Juan, Argentina.

O. Bellier and L. L. Siame, Centre Européen de Recherche et d'Enseignement de Géosciences de l'Environnement, UMR 6635, Université Paul Cézanne (Aix-Marseille III), Europôle Méditerranéen de l'Arbois, BP 80, F-13545 Aix-en-Provence cedex 04, France. (siame@cerege.fr)

M. Sébrier, Laboratoire de Tectonique, UMR 7072 Université Pierre et Marie Curie, 4 place Jussieu, 75005 Paris, France. 